Research Article

\title{
Occurrence of Citropsis articulata in Tropical Forests in Uganda: Implication for Ex Situ Conservation
}

\author{
Rapheal Wangalwa ${ }^{10},{ }^{1,2}$ Eunice Apio Olet, ${ }^{1,2}$ Grace Kagoro-Rugunda, ${ }^{1}$ \\ Casim Umba Tolo, ${ }^{1,2}$ Patrick E. Ogwang, ${ }^{2,3}$ and Bernard Barasa ${ }^{4}$ \\ ${ }^{1}$ Department of Biology, Mbarara University of Science and Technology, P.O. Box 1410, Mbarara, Uganda \\ ${ }^{2}$ Pharm-Biotechnology and Traditional Medicine Centre, Mbarara University of Science and Technology, P.O. Box 1410, \\ Mbarara, Uganda \\ ${ }^{3}$ Department of Pharmacy, Mbarara University of Science and Technology, P.O. Box 1410, Mbarara, Uganda \\ ${ }^{4}$ Department of Geography and Social Studies, Kyambogo University, P.O. Box 1, Kyambogo, Uganda \\ Correspondence should be addressed to Rapheal Wangalwa; wangarapha@must.ac.ug
}

Received 8 January 2021; Revised 28 February 2021; Accepted 4 March 2021; Published 25 March 2021

Academic Editor: Anna Źróbek-Sokolnik

Copyright (c) 2021 Rapheal Wangalwa et al. This is an open access article distributed under the Creative Commons Attribution License, which permits unrestricted use, distribution, and reproduction in any medium, provided the original work is properly cited.

\begin{abstract}
Citropsis articulata is a medicinal plant that is increasingly threatened by unsustainable methods of harvesting and habitat degradation. Owing to the fact that this plant species is highly utilized for herbal medicine and is currently restricted to a few forest reserves in Uganda, this has significant implications for ex situ conservation. Therefore, the aim of this study was to assess how physiographical factors influence the occurrence and distribution of C. articulata in the three forest reserves in Uganda, namely, Budongo, Mabira, and Kibale National Park. The study was carried out in 15 compartmental sites in each of the three forests. In each compartmental site, 4 plots of $60 \mathrm{~m} \times 60 \mathrm{~m}$ were systematically established, and within each plot, 4 subplots each of size $20 \mathrm{~m} \times 20 \mathrm{~m}$ were randomly setup. A total of 240 subplots were assessed for occurrence of Citropsis articulata in each forest. The results indicated a significant $(p<0.05)$ variation in the density of $C$. articulata with the highest recorded in Kibale National Park. Citropsis articulata generally occurred at moderate altitudinal landscapes (overall elevation $=1200.0 \pm 20.73 \mathrm{~m}$ ) with soils that are moderately acidic (overall $\mathrm{pH}=5.7 \pm 0.10$ ), low in salinity (overall salinity $=84.0 \pm 3.84 \mathrm{mg} / \mathrm{l}$ ), and moderate levels of macro- and micronutrients. Citropsis articulata was generally associated with plant communities dominated by canopy tree species of genera such as Chryosphyllum, Celtis, Markhamia, Cynometra, Lasiodiscus, Trilepisium, Funtumia, and Diospyros, thus suggesting that C. articulata is a shade-tolerant species. Establishing the ecological requirements of this plant species among other things informs the potential for ex situ production of this plant. This will not only provide alternative sources of plant harvest but also go a long way in relieving the current harvest pressures exerted on the conserved wild populations of this plant species.
\end{abstract}

\section{Introduction}

Citropsis articulata (Willd. ex Spreng) Swingle \& Kellerm, family Rutaceae, is commonly known as the African cherry orange. The plant species is native to West, Central, and East African countries including Cameroon, Central African Republic, Congo, Gabon, Ghana, Guinea, Ivory Coast, Liberia, Nigeria, Sierra Leone, Sudan, Tanzania, Togo, and Uganda $[1,2]$. Citropsis articulata is usually a shrub or small tree, ranging from 2.5 to $5 \mathrm{~m}$ in height but sporadically much taller [1, 3]. This plant species is well known for its aphrodisiac properties, and recent studies have proven its antiplasmodial potential too $[4,5]$. Unfortunately, the plant part used for its medicinal purpose is the root and thus the most harvested, and this could endanger its existence. In Uganda, the species is mainly restricted to the understory of moist evergreen forests located mainly in the Albertine rift including Budongo Central Forest Reserve and Kibale National Park but also reported in the Mabira Central Forest Reserve in Central Uganda. 
The fact that just a handful of forest reserves in Uganda act as the natural habitats of $C$. articulata could have farreaching implications. In Uganda, $61.4 \%$ of forest reserves are managed by the National Forestry Authority (NFA), whereas $33.6 \%$ are managed by Uganda Wildlife Authority (UWA), while $4.7 \%$ are jointly managed by NFA and UWA and $0.3 \%$ by local governments [6]. Under the management of National Forestry Authority, Central Forest Reserves (CFRs) were set aside to provide forest products, recreation, protect and conserve biodiversity, stabilize soils, and improve climate and protect water catchments, among others [6,7]; this includes the likes of Budongo and Mabira Central Forest Reserves. Despite the measures put in place by NFA to protect central forest reserves as stipulated in the forestry policy, prohibited activities such as illegal logging, charcoal production, and illicit harvest of nontimber forest products (NFTPs) still persist in most central forest reserves. This in part is attributable to the management weaknesses such as weak law enforcement resulting from limited staffing $[6,8]$. The predicament is further compounded by the location of some forests near metropolitan areas in addition to having settlement enclaves within the forest reserve boundaries; case in point is Mabira Central Forest Reserve. On the other hand, Kibale Forest currently managed by UWA was gazetted as a National Park in 1993, at which point management emphasized exclusive conservation with no human use allowed except for research and tourism [9]. We therefore hypothesize that these differences in forest management could impact on the occurrence of C. articulata in the three forest reserves.

Citropsis articulata is listed among the vulnerable species of Uganda according to the International Union for Conservation of Nature (IUCN) red list for Uganda [10]. Besides, Okeowo [11] noted that C. articulata is disappearing in Mabira Central Forest Reserve at an alarming rate. This was attributed to overexploitation and unsustainable methods of harvesting, owing to increased demand and commercial value for its roots [8]. Additionally, factors such as environmental degradation and climate change may further increase the vulnerability of this plant species. This therefore calls for the need to develop and enhance other conservation approaches such as ex situ conservation through offsite production (e.g., cultivation and or domestication). However, the success of any ex situ conservation program, specifically offsite production, requires understanding the ecological conditions and requirements of the plant in question in this case C. articulata. For instance, speciesspecific growth and survival responses to resources particularly physiographical factors play a key role in determining the success of species offsite production. The influence of soil factors on plant growth has been extensively studied (e.g., [12-16]). However, this information does not provide local evidence on how soil conditions impact on the occurrence of C. articulata in Ugandan forests. Furthermore, understanding coexisting vegetation assemblages of a species is key because plants are known to interact at both physical and biochemical levels which impact on a plant's regeneration and recruitment in any forest environment [17-19].
Therefore, the aim of this study was to investigate how physiographical (location, topography, and soil) factors influence the occurrence and distribution of $C$. articulata in the three forests of Uganda, namely, Budongo, Mabira, and Kibale National Park. The specific objectives were to (1) establish whether geolocation and forest management have implications on the occurrence and distribution of C. articulata, (2) determine whether soil chemical parameters have an effect on the occurrence of $C$. articulata in the three tropical forests of Uganda, and (3) determine the plant species assemblages that co-occur with C. articulata in the three forests of Uganda. The findings of this study have extensive implications: first, any indications of habitat specificity and preferences by $C$. articulata would mean that success of any offsite production would entail provision of such conditions to suit its production. Secondly, significant variation in the occurrence of $C$. articulata in the three stipulated forests would indicate that location and management strategies may have an impact on occurrence of C. articulata. Therefore, there is need for designing and implimentatng suitable and continuous monitoring programs to protect and conserve $C$. articulata and possibly curb any anthropogenic activities leading its vulnerability.

\section{Materials and Methods}

2.1. Study Area. Uganda lies across the equator in Eastern Africa between the latitudes $4.5^{\circ} \mathrm{N}$ to $1.5^{\circ} \mathrm{S}$ and longitudes $29.5^{\circ} \mathrm{E}$ to $35^{\circ} \mathrm{E}$ (Figure 1 ), at an average altitude of 1,100 meters above sea level. This study was conducted in three geolocations, i.e., Mabira Central Forest Reserve, Budongo Central Forest Reserve, and Kibale National Park (Figure 1). The three geolocations were selected based on the following criteria: (1) the presence of Citropsis articulata, (2) management status, (3) the degree of human activities in the area, providing a possibility to determine the impact of these activities, and (4) agroecological zone (AEZ) classification. The three geolocations are encircled by varying agroecological zones. The zones are characterized by different farming systems determined by soil types, climate, landforms, and socioeconomic and cultural factors [20].

2.1.1. Mabira Central Forest Reserve (MCFR). Gazetted in 1932, Mabira Central Forest Reserve (MCFR) lies partly in Buikwe, Mukono, and Kayunga districts. It occupies an area of $306 \mathrm{~km}^{2}$ and is situated between latitudes $0^{\circ} 22^{\prime} \mathrm{N}$ to $0^{\circ} 36^{\prime} \mathrm{N}$ and longitudes $32^{\circ} 50^{\prime} \mathrm{E}$ to $33^{\circ} 07^{\prime} \mathrm{E}$ with an altitudinal range of 1073-1348 $\mathrm{m}$ above sea level (Figure 2). The landscape of the forest is generally characterized by gently undulating flat-topped hills to wide shallow valleys occupied by swamps $[21,22]$. The flat-topped hills are remnants of the earlier peneplain uplifted by tectonic movements which lowered the land south of MCFR and were filled up by river water from the east and west to form present Lake Victoria [23]. The southern part of the forest is situated at or near the watershed of rivers and streams which flow into Lake Victoria and Lake Kyoga to the south and north, respectively. The geology of MCFR is characterized by the 


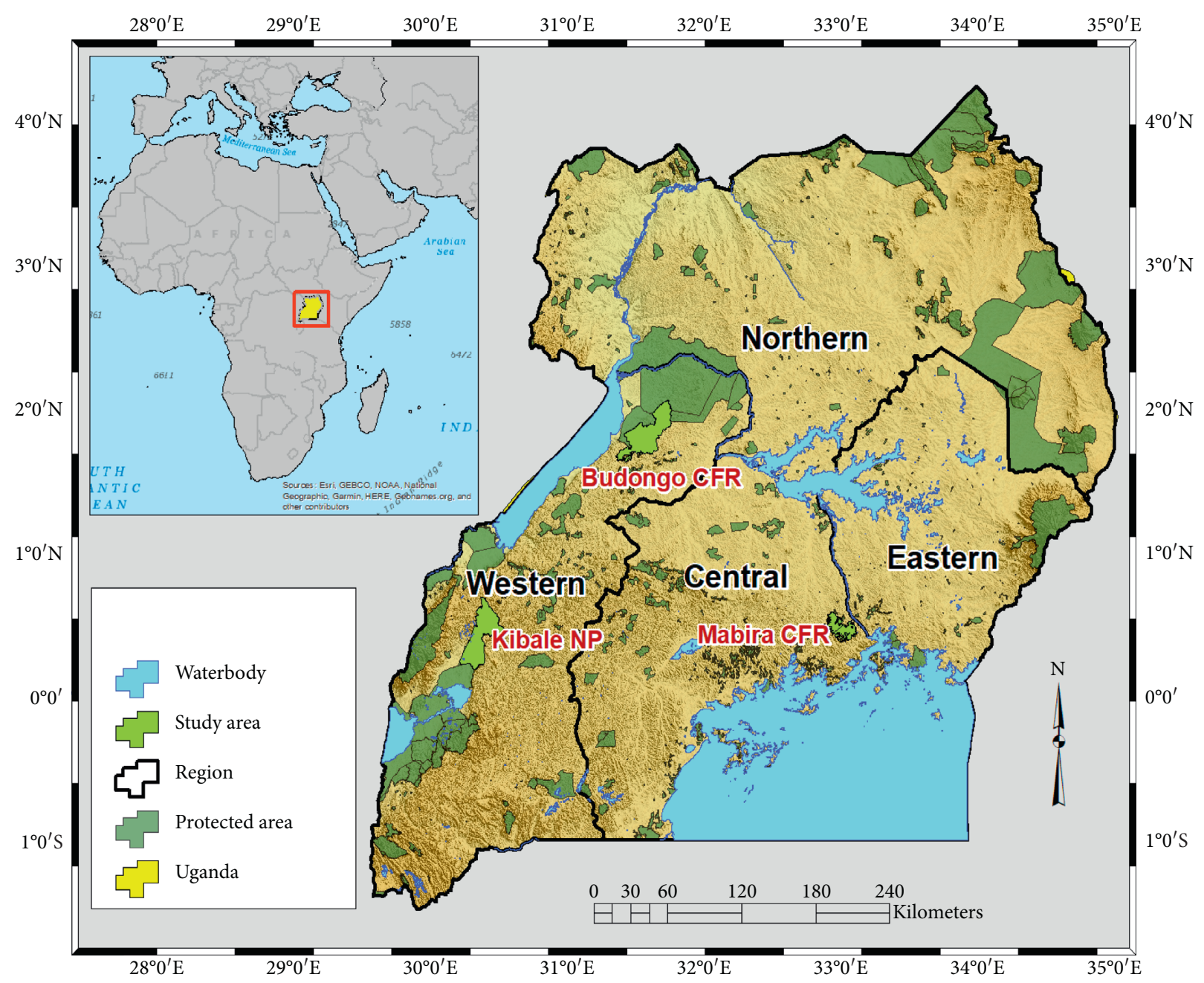

Figure 1: Location map of Budongo, Mabira, and Kibale Forest Reserves in Uganda.

Buganda-Toro system, which is made up of granitic gneiss and granites overlaid by metamorphosed sediments such as schists, phyllites, quartzites, and amphibolites [21, 23]. MCFR generally has ferrallitic sandy clay loam soils often referred to as Buganda catena and consists of red soil of incipient laterisation on slopes and black clays in the valley bottoms [21, 24]. MCFR experiences an equatorial type of climate characterized by a bimodal rainfall pattern with two wet seasons during March-May and September-November with an average annual rainfall of $1,300 \mathrm{~mm}$ [21]. The temperature is typically of the equatorial region with an average annual temperature of about $21-25^{\circ} \mathrm{C}$. The proximity of MCFR to Lake Victoria and its occurrence at altitude of more than $1,000 \mathrm{~m}$ have a moderating effect on its temperatures. Nevertheless, the MCFR zone generally displays comparatively small seasonal variations in temperature, humidity, and wind throughout the year [21]. According Langdale-Brown et al. [25], the vegetation of MCFR is classified as medium altitude moist semideciduous. However, the forest vegetation has greatly been influenced by human activities such as exploitation, cultivation, and grazing, among others; thus, the vegetation types are generally characterized by subclimax or human-altered plant communities. The forest reserve is partitioned into three management zones, i.e., strict nature reserve (in which no activities are permitted except scientific research), buffer (in which recreational activities and collection of nontimber forest products are permitted), and production (managed for sustainable supply of timber forest products) $[8,21]$. The forest is also masked with village enclaves that are widely distributed within the forest area (Figure 2). The residents of these enclaves largely depend on the forest resources for their livelihood [26], and this may render management of the forest reserve an uphill task. In addition, due to high proximity to metropolitan areas such as Kampala and Jinja, the MCFR area has been subjected to deforestation for agriculture and logging [27]. MCFR is currently managed by National Forestry Authority (NFA) in accordance with the current forestry policy and legal framework [21]. The management plan of the forest prohibits charcoal production and harvesting of resources in large quantities for commercial but allows extraction of food materials, medicine, poles, and fallen logs for firewood in low quantities for subsistence use $[21,28]$. 


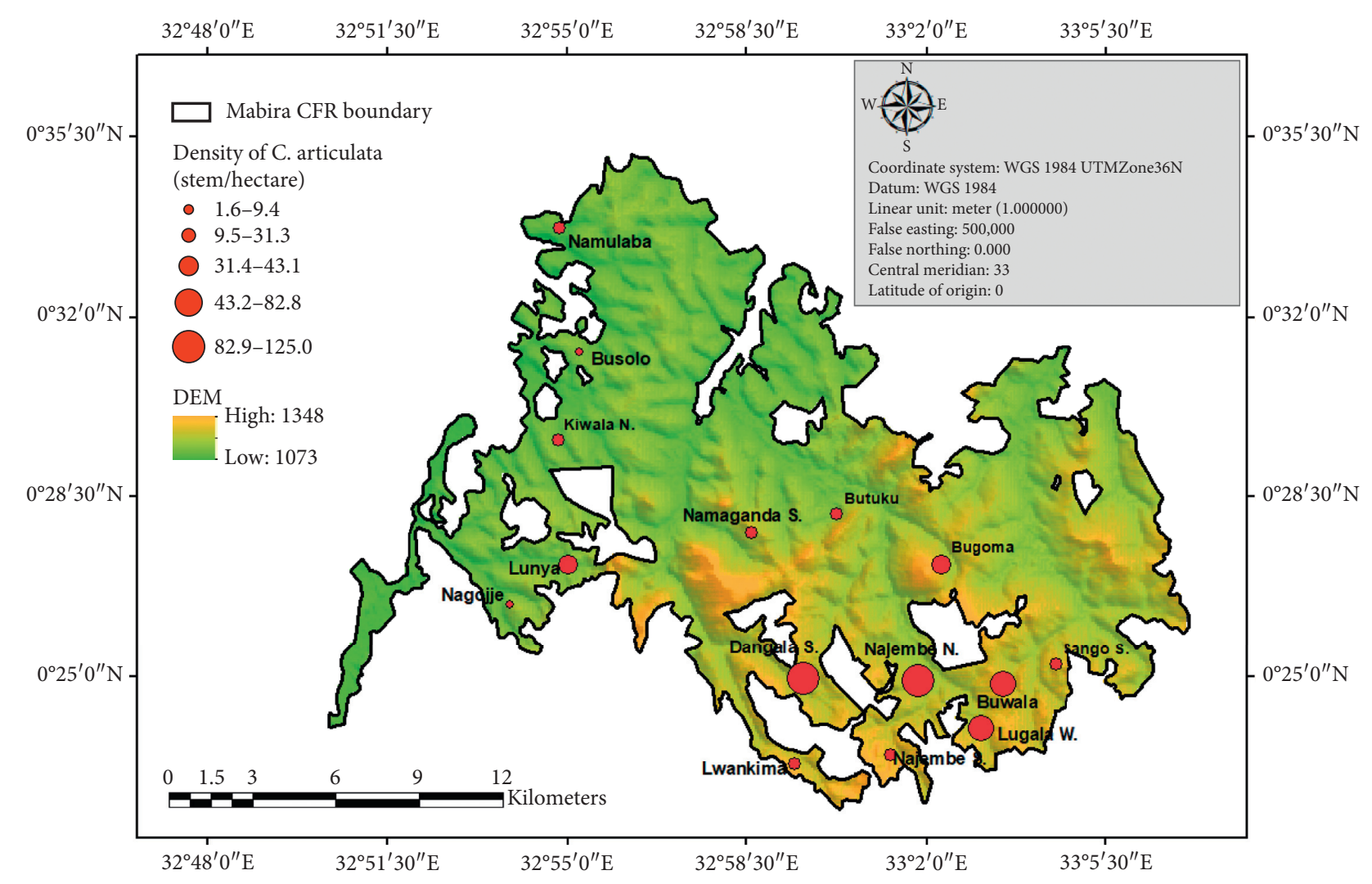

FIgure 2: Variability in occurrence of C. articulata in Mabira Central Forest Reserve.

2.1.2. Budongo Central Forest Reserve. Budongo Central Forest Reserve (BCFR), gazetted in 1932, lies partly in Buliisa, Hoima, and Masandi districts. It covers an area of $825 \mathrm{~km}^{2}$ making it Uganda's largest Central Forest Reserve. The forest is situated between the latitudes $1^{\circ} 37^{\prime} \mathrm{N}$ and $2^{\circ} 4^{\prime} \mathrm{N}$ and longitudes $31^{\circ} 20^{\prime} \mathrm{E}$ and $31^{\circ} 48^{\prime} \mathrm{E}$ with an altitudinal range of $719 \mathrm{~m}-1,258 \mathrm{~m}$ above sea level (Figure 3 ). The forest lies towards the north end of lake Albert, on the gentle upper slopes of the watershed, with its western edge only $3-6 \mathrm{~km}$ from the top of the escarpment of the western rift valley [29]. The terrain of the forest is characterized by gently undulating hills with generally soft valley bottoms marked with several streams. Majority of the streams join to form two rivers (Sonso and Weisoke) as they approach the western margin of the forest [29]. The forest experiences an equatorial type of climate characterized by a bimodal rainfall pattern with two wet seasons during March-May and September-November with an average annual rainfall of 1,150-1,500 mm. Minimum annual temperature ranges from 17 to $20^{\circ} \mathrm{C}$, while the maximum annual temperature is in a range of 28 to $29^{\circ} \mathrm{C}$ [30]. The geology of the forest comprises rocks of ancient gneisses, schists, and granites of basement complex, covered by the Bunyoro series sediments. The forest is generally underlain with ferralitic soils, mainly sandy to sandy clay loam of low to moderate fertility $[22,29,30]$. BCFR has been described as a lowland moist semideciduous forest with varying vegetation characteristics, namely, Cynometra forest, mixed forest, colonizing forest (woodland), and swamp forest. The forest is mainly dominated by plant species of
Cynometra, Celtis, and the mahoganies Khaya and Entandrophragma species [22, 29]. In addition, Budongo Central Forest Reserve is home to some of Uganda's major fauna including approximately 150 species of forest birds and 5 species of diurnal forest primates such as chimpanzees (Pan troglodytes). This renders BCFR a forest of high importance for global biodiversity and ranking third in overall importance of Ugandan forests [31-33]. The forest has a history of selective logging which occurred since 1910, intensified between 1935 and 1960 when mechanical logging operated in the forest, and was reduced in the early seventies [34, 35]. Due to overexploitation, enrichment planting of mahogany (Khaya and Entandrophragma) was carried out to encourage its regeneration. The 1950 s and 1960s also witnessed the use of arboricide treatment on trees considered of less or no commercial value $[35,36]$. A number of human activities occur around the forest with agriculture as the major economic activity. Commercial sugarcane production and growing of crops such as Musa sp. (Banana), Manihot esculenta (Cassava), Phaseolus vulgaris (Beans), Zea mays (Maize), and Eleusine coracana (Millet), among others, are evident at forest's edge. BCFR is managed by National Forestry Authority (NFA) in accordance with the current forestry policy and legal framework [21]. The management plan of the forest prohibits charcoal production and harvesting of resources in large quantities for commercial purpose but allows extraction of food materials, medicine, poles, and fallen logs for firewood in low quantities for subsistence use $[21,28]$. Despite the tremendous efforts 


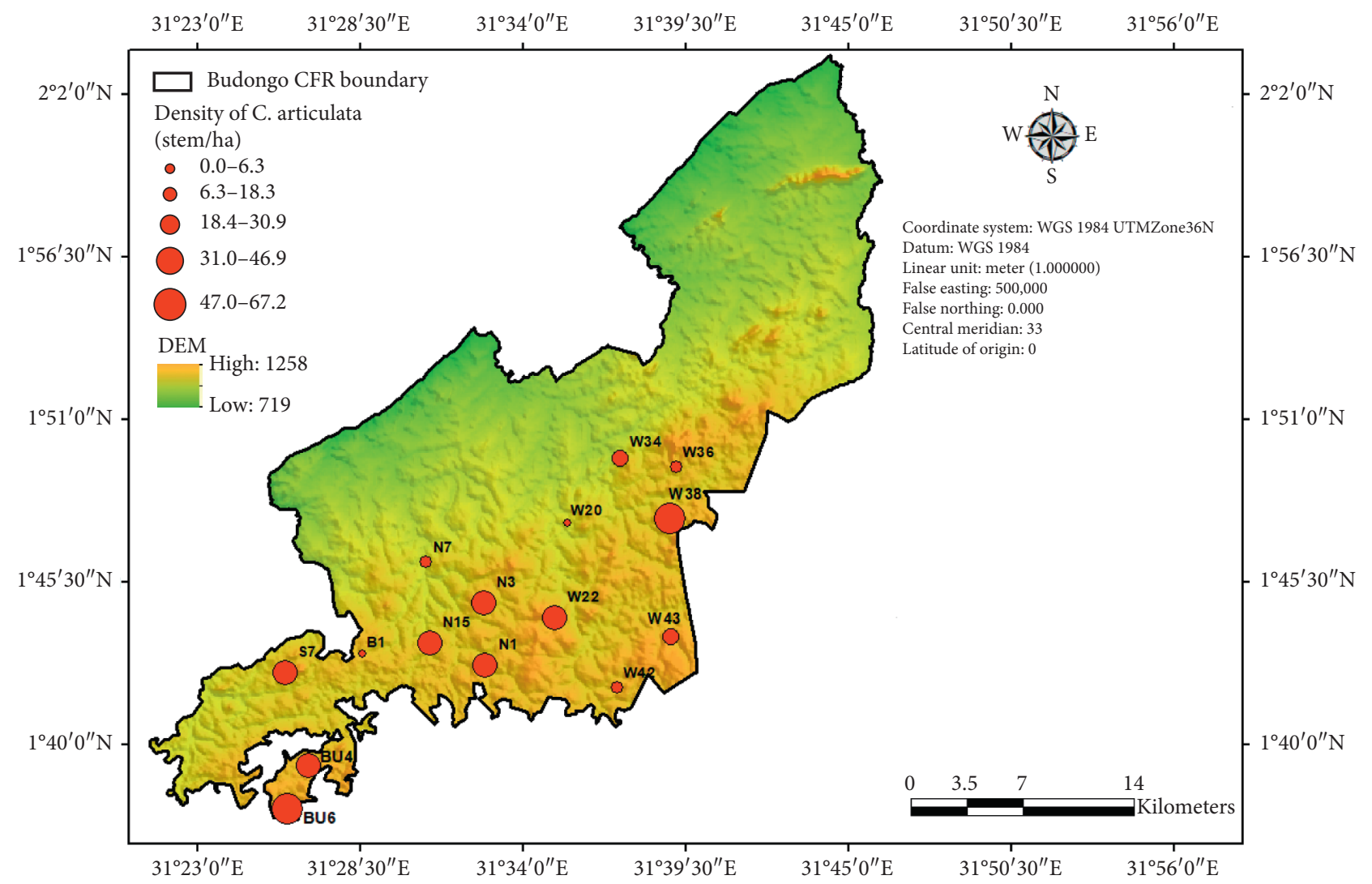

Figure 3: Variability in occurrence of C. articulata in Budongo Central Forest Reserve. B, Biso; Bu, Busaju; N, Nyakafunjo; S, Siiba; W, Waibira.

made by the Uganda government and NFA to protect the forest and its resources, the forest is still grappling with the problems of illegal logging and charcoal production.

2.1.3. Kibale National Park. Kibale Forest was gazetted in 1932 as a Forest Reserve and later elevated to National Park status in 1993 and is currently under the management of Uganda Wildlife Authority (UWA) [37, 38]. Kibale National Park is situated in western part of Uganda traversing Kabarole, Kamwenge, and Kyenjojo districts. The forest is located $22 \mathrm{~km}$ south of Fort Portal City near the foothills of the Rwenzori mountains and positioned between latitudes $0^{\circ} 13^{\prime} \mathrm{N}$ and $0^{\circ} 41^{\prime} \mathrm{N}$ and longitudes $30^{\circ} 10^{\prime} \mathrm{E}$ and $30^{\circ} 35^{\prime} \mathrm{E}$ (Figure 4). Furthermore, the park is a medium-altitude tropical moist forest covering about $795 \mathrm{~km}^{2}$ with an altitudinal range of $926 \mathrm{~m}-1,619 \mathrm{~m}$ above sea level (Figure 4). The park is situated in an undulating landscape on the main Uganda plateau, slightly tilted to the south, and is drained by the Mpanga and Dura rivers flowing in a southerly direction and emptying into Lake George $[39,40]$. The park experiences an equatorial type of climate characterized by a bimodal rainfall pattern with two wet seasons during March-May and September-November with an average annual rainfall between 1,100 and $1,600 \mathrm{~mm}$. The park experiences moderate temperatures with minimal fluctuations over the year. The average monthly minimum temperature is $15^{\circ} \mathrm{C}$, whereas the average monthly maximum temperature is $27^{\circ} \mathrm{C}$ [37]. The geology of the park consists of rocks formed in the
Precambrian period which were successively folded and metamorphosed. The Buganda-Toro system overlying these rocks forms noticeable ridges of quartzite, schists, and phyllites with bodies of amphibiolites, gneisses, and granites [38]. The park is generally underlain by red ferralitic soils, comprising sandy clay loams in the north and clay loams in the south. The soils are deeply weathered, exhibit weakly developed horizons, and are of very low to moderate fertility $[38,41]$. The park comprises moist semideciduous and evergreen forest (57\%), grassland (15\%), woodland (4\%), lakes and wetlands (2\%), colonizing forest (19\%), and plantations of exotic trees (1\%) [42]. The park provides critical habitat to eastern chimpanzees (Pan troglodytes schweinfurthii), 12 additional primate species, elephants (Loxodonta africana), and a diversity of other species [42]. The forest was immensely exploited as a source of commercial timber in 1950s, while still a forest reserve, and thus, a number of compartments are currently at various stages of regeneration [40, 43]. The current management plan of the park incorporates a number of conservation strategies including resource conservation and management, enforcing boundaries, policing against illegal resource extraction, research and ecological monitoring, restoring degraded areas within the park, and tourism $[9,43]$.

2.2. Study Sampling Design and Data Collection. For comparative purposes, the study was carried out in 15 compartments/sites in each of the three study forest reserves, i.e., Budongo, Mabira, and Kibale. The 15 study compartments/ 


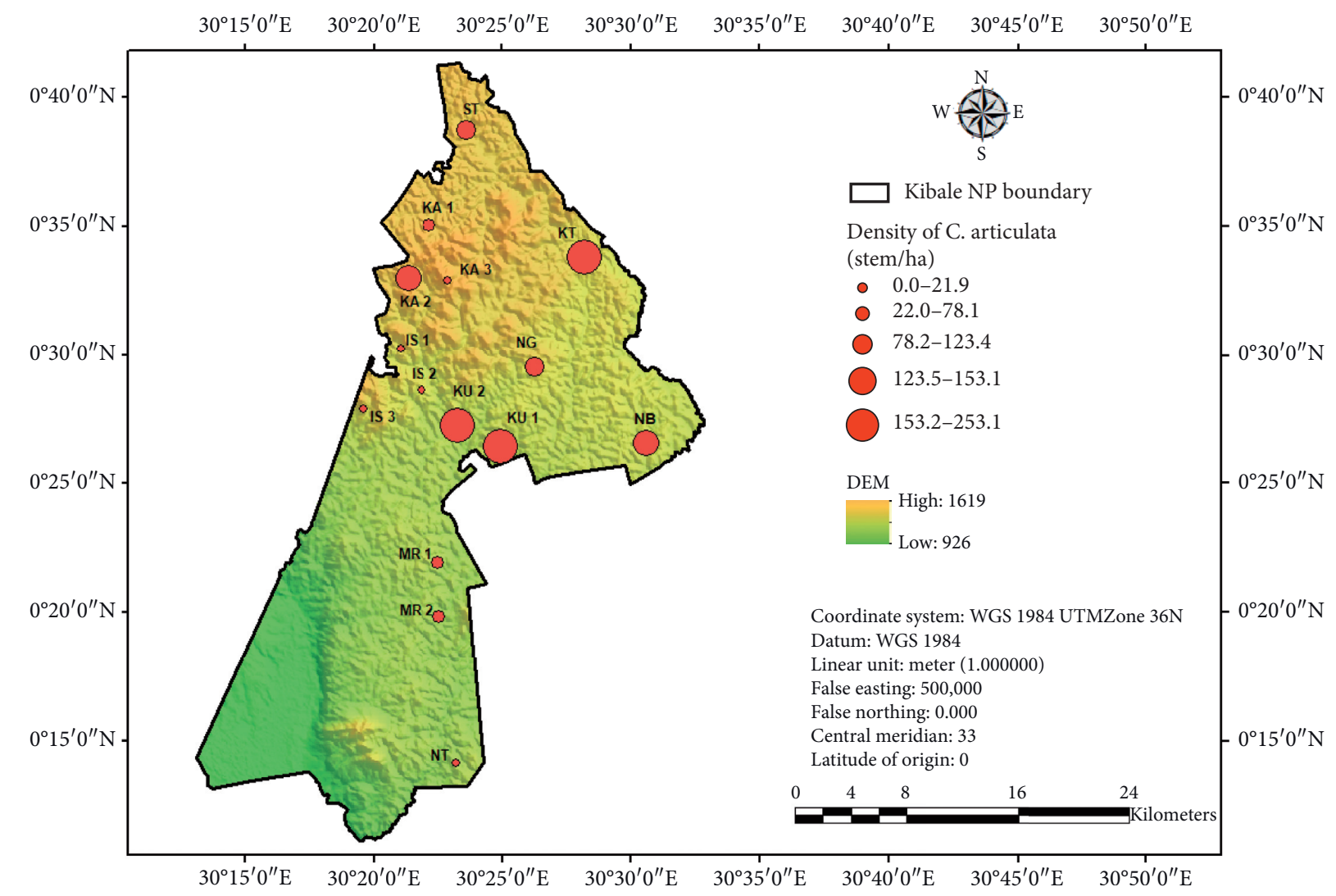

FIgUre 4: Variability in occurrence of C. articulata in Kibale National Park. KA, Kanyawara; ST, Sebitoli; IS, Isunga; NG, Ngogo; KU, Kanyanchu; MR, Mainaro; NB, Nyamibiriko; NT, Nyabitusi; KT, Kinyantale.

sites were selected from the forest maps with the intent of attaining sufficient extent of spatial coverage of the forest reserve. In each compartmental site, 4 plots of $60 \mathrm{~m} \times 60 \mathrm{~m}$ (1.4 ha) were established systematically with the first sample plot selected randomly and the subsequent plots established at an interval of $100 \mathrm{~m}$ from either side of the first plot; within each plot, 4 subplots each of size $20 \mathrm{~m} \times 20 \mathrm{~m}$ (0.04 ha) were established randomly following McRoberts et al. [44]. Therefore, a total of 240 subplots $(20 \mathrm{~m} \times 20 \mathrm{~m})$ were assessed for occurrence of $C$. articulata in each forest.

Within each plot, the number of individuals of $C$. articulata was recorded and georeferenced using a hand-held GPS (Garmin GPSMAP ${ }^{\circledR} 64$ ) and visualized in ArcMap version 10.5 (Esri. ArcGIS ${ }^{\circledR}$ ). To establish the occurrence of $C$. articulata with other plant species, tree and shrub plant species occurring within the subplot of occurrence of $C$. articulata were identified to species level with the assistance of forestry experts and botanists from National Forestry Authority, Budongo Conservation Field Station, and Makerere University Biological Field Station for Mabira, Budongo, and Kibale forests, respectively. The identities of the species were verified using plant species lists from Budongo Conservation Field Station, National Forestry Authority (NFA), and field guide by Hamilton [45], Kalema and Beentje [46], and Katende et al. [47]. The frequency of occurrence of each individual species at site of occurrence of $C$. articulata was expressed as a percentage using the following formula: percentage occurrence of species $(Y)$

$$
=\frac{\text { number of plots with species }(Y)}{\text { total number of plots with C. } \operatorname{articulata}} \times 100 \text {. }
$$

Soil samples were collected at the site of occurrence of C. articulata following methods by Burt [48]. The soil samples were collected from five (5) subsites within each subplot of occurrence of C. articulata at a standard depth of $0-30 \mathrm{~cm}$ and mixed thoroughly to form a homogenous composite sample before placing $500 \mathrm{~g}$ soil sample in a clean zip lock plastic bag. The samples were labeled appropriately for reference and transported to Mbarara University of Science and Technology, Biology laboratory for chemical analysis. The soil was air-dried and analyzed for 13 soil chemical parameters $(\mathrm{pH}$, conductivity, salinity, phosphorus, potassium, magnesium, calcium, aluminium, chloride, copper, iron, manganese, and sulphur) using the SKW 500 Complete Soil Kit by Palintest ${ }^{\circledR}$. The soil samples were prepared and analyzed for each chemical parameter using procedure and guidelines specified by the soil kit manufacturer (Palintest ${ }^{\circledR}$ ).

2.3. Data Analysis. Density of C. articulata was computed by converting the count from all sample plots into a hectare basis and presented as mean \pm standard error (SE). Variation 
in density and height of C. articulata in the three forests of Mabira, Budongo, and Kibale were tested using one-way ANOVA (F test), and consequently, Tukey's multiple comparison test used to determine where the means were different at $p<0.05$ in GraphPad Prism version 6.0 (GraphPad Software Inc., USA). The relationship between density of $C$. articulata and altitude and soil chemical parameters was determined using Pearson product-moment correlation coefficient. Data of soil chemical properties were analyzed using a statistical Kruskal-Wallis test, and consequently, Dunn's multiple comparison test used to determine where the medians were different at $p<0.05$ in GraphPad Prism version 6.0 (GraphPad Software Inc., USA). Relationships between soil chemical parameters were established using Spearman's rank correlation test. Principal component analysis (PCA) was used in the multivariate analysis of soil chemical parameters using Minitab (Minitab Inc., USA).

\section{Results and Discussion}

3.1. Occurrence of C. articulata. A total of 1686 C. articulata individual plants were recorded in the three forests, with Kibale National Park having the highest abundance of 974 individuals followed by Mabira (414 individuals), whereas Budongo had the lowest abundance of C. articulata (298 individuals). Density of the C. articulata varied significantly $(p<0.05)$ in the three forests (Figure 5(a)). Kibale National Park had the highest density of C. articulata with a mean of 100.2 stems ha ${ }^{-1}$, while Budongo Central Forest reserve presented the lowest average density of 30.9 stems ha $^{-1}$, as indicated in Figure 5(a). The high occurrence of C. articulata in Kibale National Park may be attributable to the differences in management practices and strategies for National Parks and Central Forest Reserves. Kibale National Park under the management of Uganda Wildlife Authority (UWA) enjoys the benefits of stricter laws and regulations governing National Parks and perhaps better enforcement compared to Mabira and Budongo Central Forest Reserves that are currently under the management of National Forestry Authority (NFA). Throughout the entire course of this study, illegal activities such as deforestation and charcoal production were not evidenced in Kibale National Park. However, these were more evident in Budongo and Mabira Central Forest Reserves. Occurrence of these illegal activities in the forest reserves can lead to incidental cutting of C. articulata by users seeking resources from the forest [8]. In addition, this phenomenon can as well lead to harvest of C. articulata by those who know its medicinal value, thus negatively impacting on its abundance. Important to note is that Kibale National Park is generally located at high altitude compared to Budongo and Mabira Central Forest Reserves, a factor which may have also influenced the abundance of C. articulata. As shown in Figure 5(d), density of C. articulata was found to be positively associated with elevation. The variation in the soil chemical parameters of the three forests may also have further influenced the abundance and distribution of $C$. articulata since soil properties have been reported to be a vital variable in shaping plant species distribution in tropical forests [49]. It is worth noting that other conditions and factors such as climate, herbivory, and disease may also strongly impact on the abundance and distribution this plant species in the three forests.

In Kibale National Park, C. articulata was majorly abundant in the compartmental sites of Kanyanchu and Kinyantale with densities in the range of 153.2-253.1 stems $\mathrm{ha}^{-1}$ (Figure 4). In Mabira Central Forest Reserve, C. articulata was majorly abundant in the compartmental sites of Najjembe North and Dangala South with density in the range of 89.2-125.0 stems ha ${ }^{-1}$ (Figure 2). In Budongo Central Forest Reserve, C. articulata was abundant in compartmental sites of Busaju ( $\mathrm{Bu} 6$ ) and Waibira (W 38) with densities in the range of 47.0-67.2 stems ha ${ }^{-1}$ (Figure 3). High density of C. articulata in these sites could mean that these sites have conducive environmental conditions and thus preferred habitats of $C$. articulata. For instance, common features observed at these sites are that they are all located along gentle slopes and near noticeable streams, conditions which could have favored proliferation of C. articulata.

C. articulata showed significant variation $(p<0.05)$ in plant height among individuals from the three forests (Figure 5(b)). In Mabira Central Forest Reserve, plant height ranged from $0.1 \mathrm{~m}$ to $8.7 \mathrm{~m}$ and a mean height of $3.1 \pm 0.12 \mathrm{~m}$, making this the highest mean height recorded in the study. In Kibale National Park, plant height ranged from $0.2 \mathrm{~m}$ to $8.5 \mathrm{~m}$ and a mean height of $2.8 \pm 0.08 \mathrm{~m}$, making this the second highest height recorded in this study. On the other hand, the plant height of $C$. articulata in Budongo Central Forest Reserve was in a range of $0.1 \mathrm{~m}$ to $5.2 \mathrm{~m}$ and a mean of $1.5 \pm 0.06 \mathrm{~m}$, thus making this the lowest mean height of $C$. articulata recorded in this study. The stems of C. articulata in Budongo Central Forest Reserve were generally short compared to its counterparts in the other two forests which may be attributable to the varying soil conditions in the different forests. Budongo soils generally had a higher salinity compared to other forests. Salinity is reported to be a serious environmental factor limiting the productivity of plants because some plants are sensitive to salinity caused by high concentrations of salts in the soil [50]. There is also a likelihood that the communities surrounding Budongo Central Forest Reserve are more knowledgeable about the medicinal value of this plant and thus leading to more harvesting pressure. This could limit the plants ability to reach considerable heights when compared with counterparts in the other forests (KNP and MCFR). It is expected that the more wide spread the knowledge is about a medicinal plant, the more the harvesting pressure exerted on the plant. It is also worth noting that the use of arboricide treatment on trees considered of less or no commercial value was witnessed in Budongo Central Forest since the 1950s till 1970s [35], an action which may have affected the earlier establishment and growth of C. articulata resulting in the low heights recorded in this study.

In this study, elevation of occurrence of C. articulata varied significantly $(p<0.05)$ in the three forest reserves. 


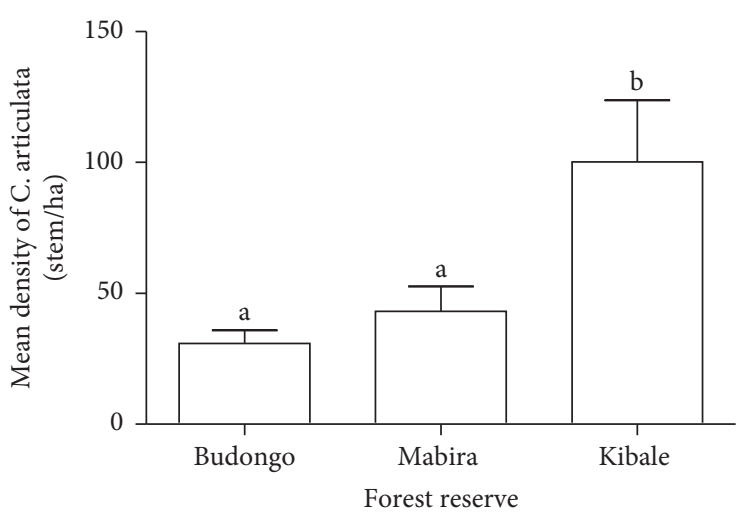

(a)

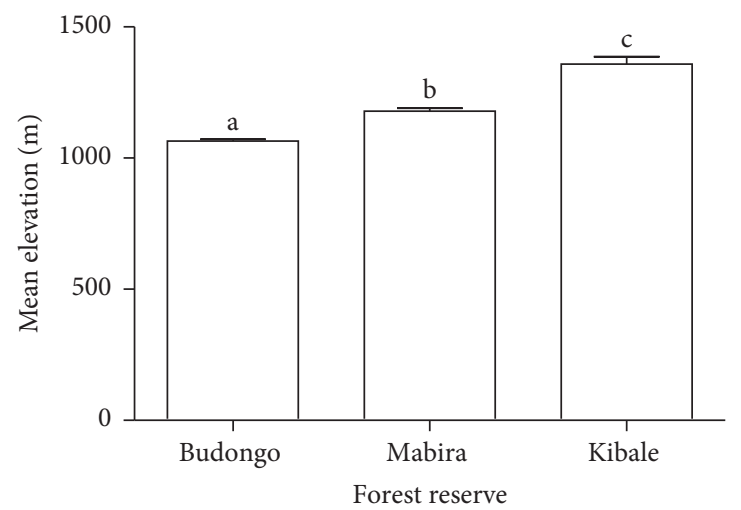

(c)

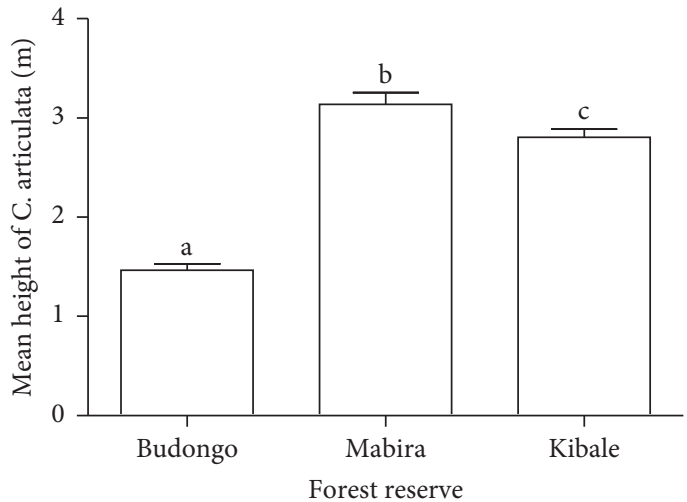

(b)

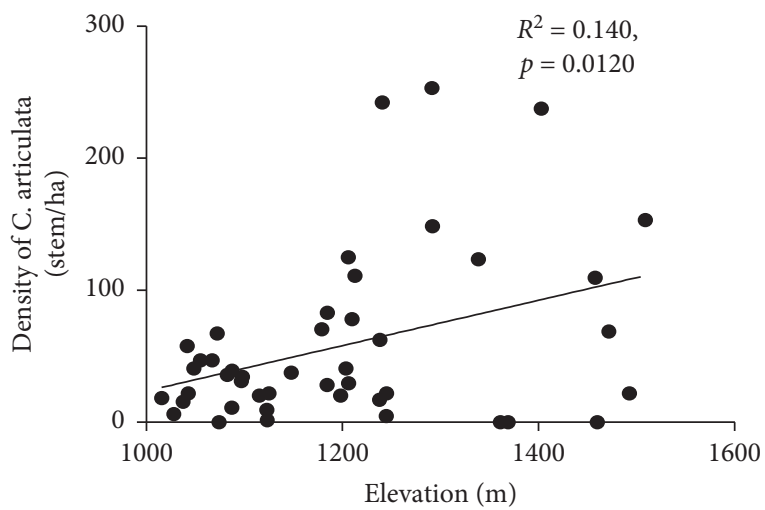

(d)

Figure 5: (a) Variation in density of C. articulata in three forests of Uganda. (b) Variation in height of C. articulata. (c) Altitudinal variation in site of occurrence of $C$. articulata in three forests of Uganda (habitat of C. articulata). Error bars represent standard error, and column bars with different lowercase letters indicate significant difference at $p<0.05$ based on Tukey's multiple comparison test. (d) Relationship between density of $C$. articulata and altitude.

Kibale National Park had the highest elevation of occurrence of C. articulata with a mean of $1358.0 \pm 26.59 \mathrm{~m}$. On the other hand, Budongo Central Forest Reserve presented the lowest altitude of occurrence of $C$. articulata with a mean elevation of $1064.0 \pm 7.59 \mathrm{~m}$ (Figure $5(\mathrm{c})$ ). The results also showed a significant positive relationship $(p<0.05)$ between density of C. articulata and elevation (Figure 5(d)). Citropsis articulata generally had high occurrence at moderate elevation levels. Elevation partially influences microenvironment of tropical forest ecosystems by controlling the spatial redistribution of light, temperature, water availability, and soil nutrients, thereby affecting understory plant species [51]. Furthermore, Ohdo and Takahashi [52] report that increase in elevations leads to an increase in climatic stress that consequently reduces the canopy height resulting in an increase in the number understory flora. This may therefore explain the high occurrence of $C$. articulata at moderate elevation levels.

3.2. Soil Chemical Parameters. Results of the present study indicate a considerable degree of soil variability in the three forests based on soil chemical parameters as indicated by the principal component analysis (Figure 6). This may be attributable to the variability in the parent material, geolocation, and environmental factors. The aforementioned factors often impact and bring about variation in the soil chemical parameters as described below.

Soil $\mathrm{pH}$ is arguably one of the most informative measurements that can be made to determine soil characteristics. Just by looking at $\mathrm{pH}$, one can tell much more about a soil than merely indication of whether it is acidic or alkaline [53]. For instance, soil $\mathrm{pH}$ is known to govern many plant soil chemical relations, predominantly the availability of micronutrients and toxic ions, owing to its influence on solubility [15]. The results of this study indicated that C. articulata generally occurs in moderately acidic soils. The highest $\mathrm{pH}$ (median $=5.95$ ) was recorded in Budongo Central Forest Reserve, while Kibale National Park presented the lowest $\mathrm{pH}($ median $=5.63)$; however, the soil $\mathrm{pH}$ did not vary significantly $(p>0.05)$ in the three forests (Figure 7(a)). Tropical forests are known to have acidic soils, owing to the enormous amounts of precipitation that often leads to increased soil acidification through weathering and leaching [54, 55]. However, in some cases, production of carbonic acids from intensive root and microbial respiration has been described to be a major contributing factor to soil acidification [56]. These two phenomena could explain the 
low $\mathrm{pH}$ observed in the three forest areas. Nevertheless, at low $\mathrm{pH}$, the availability of essential micronutrients such as iron $(\mathrm{Fe})$, manganese $(\mathrm{Mn})$, copper $(\mathrm{Cu})$, and zinc $(\mathrm{Zn})$ is increased [15, 57].

Soil electrical conductivity (EC) provides a simple electrochemical indication of the level of soluble salts present in soil. It is an important indicator of soil health and affects plant yields, suitability, and nutrient availability, in addition to influencing activity of soil microorganisms which influence key soil processes [58]. The optimal electrical conductivity of any plant is species specific and depends on environmental conditions [59,60]. In this study, electrical conductivity of the soil at site of occurrence of C. articulata varied significantly $(p<0.05)$ in the three forests with EC ranging from 57.8 to $450.8 \mu \mathrm{S} / \mathrm{cm}$ (Figure $7(\mathrm{~b})$ ). The highest EC (median $=208.5 \mu \mathrm{S} / \mathrm{cm}$ ) was recorded in Budongo Central Forest Reserve, while Kibale National Park presented the lowest EC (median $=112.3 \mu \mathrm{S}$ / $\mathrm{cm}$ ). The variation in the soil electrical conductivity in the three forests may be due to the varying microclimatic conditions and soil mineral content [58]. This is also supported by the positive relationship between salinity and electrical conductivity indicated in Table 1 . The notably high electrical conductivity in Budongo Central Forest Reserve may have impacted on the productivity of $C$. articulata as demonstrated by the low abundances and plant heights recorded in this study. This is also evident in the negative relationship $(-0.446, p=0.02)$ between EC and occurrence of C. articulata shown in Figure 8(a). High electrical conductivities are known to induce nutrient stress and enhance plant antioxidant enzyme activities, thus suppressing plant growth and quality [60].

Soil salinity impacts on several aspects of plant development such as germination, vegetative growth, and reproductive development [50]. In this study, soil salinity at site of occurrence of $C$. articulata varied significantly $(p<0.05)$ in the three forests with salinity levels ranging from 32.8 to $230.3 \mathrm{mg} / \mathrm{l}$ (Figure $7(\mathrm{c})$ ). The highest salinity levels (median $=103.0 \mathrm{mg} / \mathrm{l}$ ) were recorded in Budongo Central Forest Reserve, whereas Kibale National Park presented the lowest soil salinity (median $=58.5 \mathrm{mg} / \mathrm{l}$ ). This variation may also be attributable to variation in soil mineral content and microclimatic conditions in the three forests. It is important to note that high concentrations of salts such as sodium chloride and sodium sulfate in soil may interfere with the absorption of water by plants. This is because the osmotic pressure in the soil solution is nearly as high as or higher than that in the plant cells. Additionally, high salinity levels also interfere with the exchange capacity of nutrient ions, thereby resulting into osmotic stress, nutrient deficiency, and oxidative stress in plants [50,58]. The negative relationship between salinity and occurrence of $C$. articulata $(r=-0.465, p=0.015)$, as indicated in Figure 8(b), is more evidence to this.

Phosphorous $(\mathrm{P})$ is one of the key macronutrients and a critical determinant of plant growth and productivity, and its availability can influence growth of plants in forest ecosystems [61-63]. In the present study (Figure 7(d)), soil phosphorus content varied significantly among the three forests

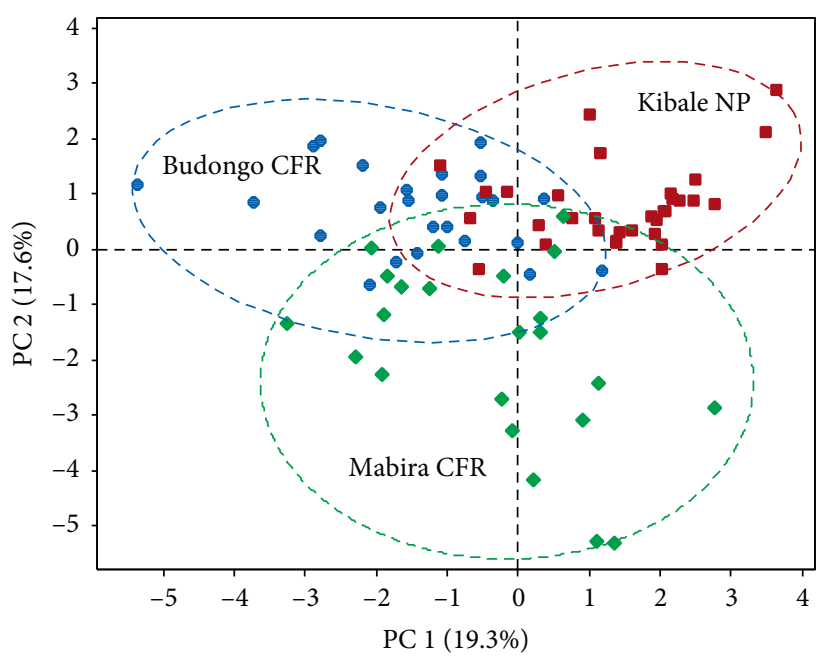

Forest

- Budongo CFR

- Kibale NP

- Mabira CFR

Figure 6: Principal component analysis of soil chemical parameters for Budongo Central Forest Reserve, Mabira Central Forest Reserve, and Kibale National Park in Uganda.

$(p<0.05)$. This was highest in soils from Kibale National park with a median value of $51.4 \mathrm{mg} / \mathrm{l}$ and lowest in soils from Budongo Central Forest Reserve (median $=7.5 \mathrm{mg} / \mathrm{l}$ ). In addition to geochemical processes, site conditions such as rainfall, temperature, moisture, soil aeration, and salinity often affect the rate of $\mathrm{P}$ mineralization from organic matter decomposition and thus phosphorus content in the soil $[58,64]$. In this case, the low phosphorus levels in soils of Budongo Central Forest Reserve could be attributable to the high salinity and consequently EC levels, which are known to lower phosphorus content of soil [50]. This is also evidenced by the negative correlation between phosphorus and EC and salinity (Table 1). On the one hand, the results indicated a positive relationship between soil phosphorus content and occurrence of C. articulata (Figure 8(c)). This may be attributed to the fact that sufficient phosphorus levels encourage vigorous root and shoot growth, promote early maturity, and increase water use efficiency and plant yield. On the other hand, $\mathrm{P}$ deficiency is known to stunt vegetative growth and plant yield [58]. On this note, the low phosphorus levels in the soils of Budongo Central Forest Reserve may account for the short C. articulata plant stems (Figure 5(b)).

In the present study, potassium $(\mathrm{K})$ content in soils at site of occurrence of $C$. articulata varied significantly $(p<0.05)$ in the three forests with potassium levels ranging from 60.0 to $850.0 \mathrm{mg} / \mathrm{l}$ (Figure 7(e)). The highest potassium levels $($ median $=220.8 \mathrm{mg} / \mathrm{l}$ ) were recorded in Kibale National Park, whereas Mabira Central Forest Reserve presented the lowest potassium levels (median $=105.0 \mathrm{mg} / \mathrm{l}$ ). The variation in the amounts of $\mathrm{K}$ in the soils from the three forest reserves may be attributed to the fact that soil potassium is affected by differences in soil parent material/rock and the weathering process [65]. The results also indicated a positive relationship between soil potassium and occurrence 


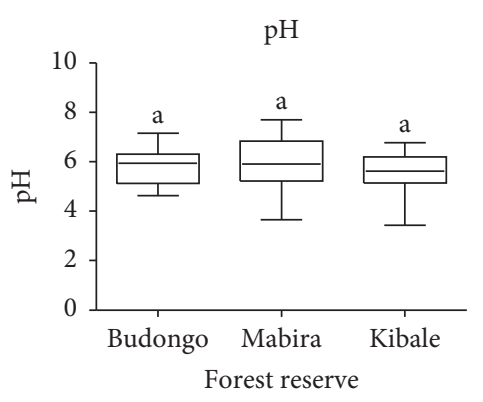

(a)

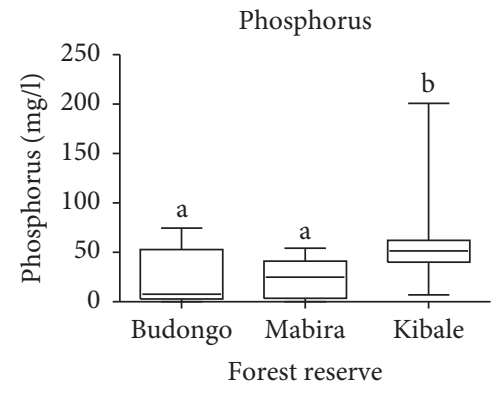

(d)

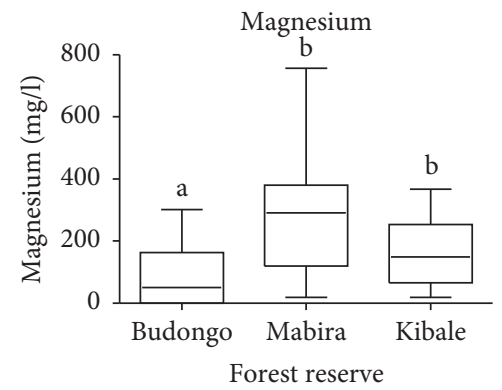

(g)

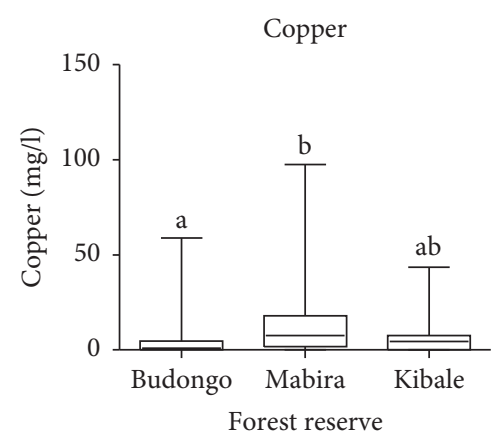

$(\mathrm{j})$

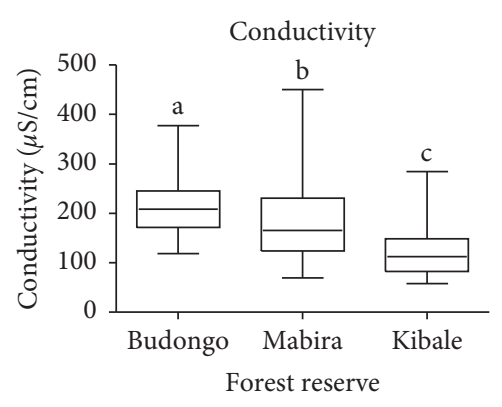

(b)

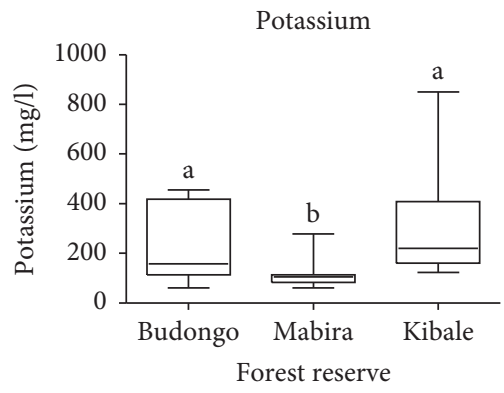

(e)

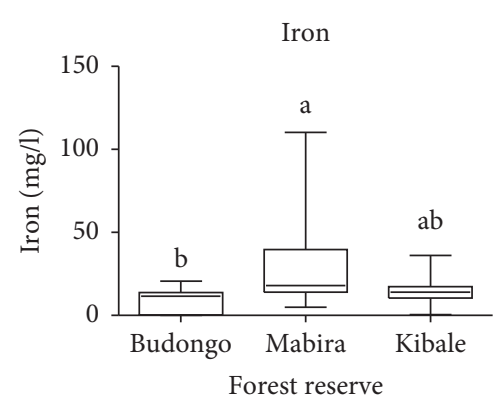

(h)

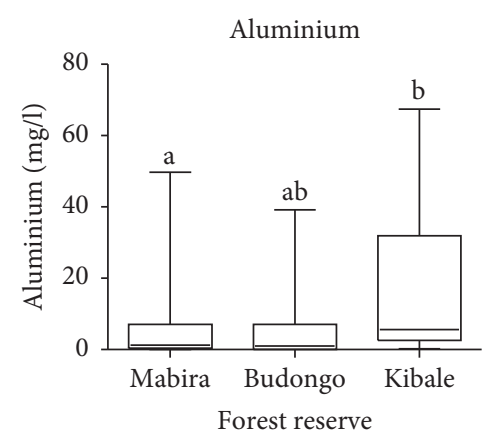

(k)

Chloride

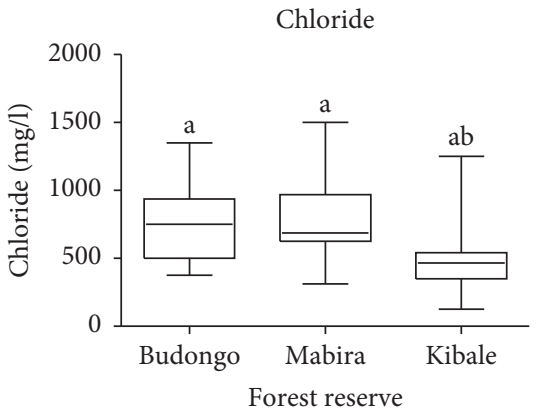

(m)

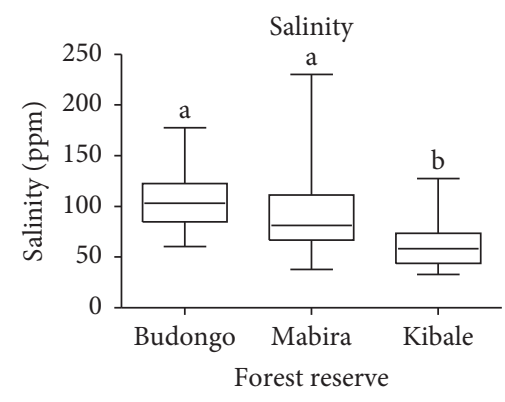

(c)

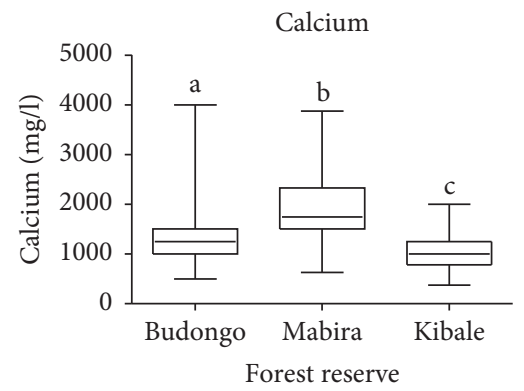

(f)

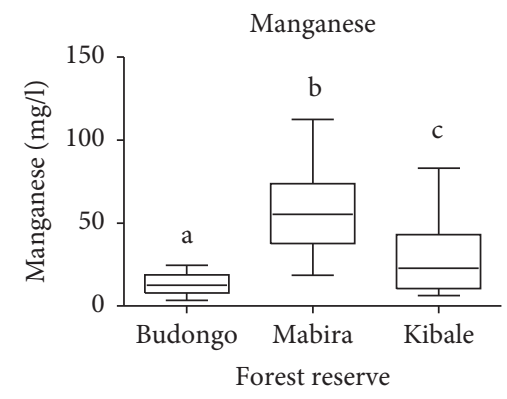

(i)

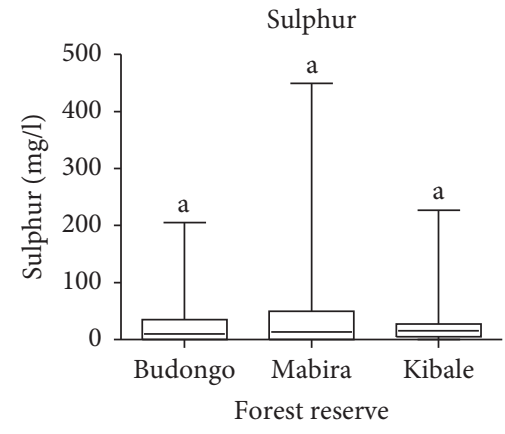

(l)

FIGURE 7: (a-m) Variation in the soil chemical parameters at site of occurrence of C. articulata in three forest reserves in Uganda. Box and whiskers with different lowercase letters indicate significant difference at $p<0.05$ based on Dunn's multiple comparison test. 
TABLE 1: Associations between soil chemical parameters.

\begin{tabular}{|c|c|c|c|c|c|c|c|c|c|c|c|c|}
\hline Parameter & $\mathrm{pH}$ & $\begin{array}{c}\text { Conductivity } \\
(\mu \mathrm{S} / \mathrm{cm})\end{array}$ & $\begin{array}{c}\text { Salinity } \\
(\mathrm{mg} / \mathrm{l})\end{array}$ & $\begin{array}{c}\mathrm{P} \\
(\mathrm{mg} / \mathrm{l}) \\
\end{array}$ & $\mathrm{K}(\mathrm{mg} / \mathrm{l})$ & $\begin{array}{c}\mathrm{Ca} \\
(\mathrm{mg} / \mathrm{l})\end{array}$ & $\begin{array}{c}\mathrm{Mg} \\
(\mathrm{mg} / \mathrm{l}) \\
\end{array}$ & $\begin{array}{c}\mathrm{Fe} \\
(\mathrm{mg} / \mathrm{l})\end{array}$ & $\begin{array}{c}\mathrm{Mn} \\
(\mathrm{mg} / \mathrm{l}) \\
\end{array}$ & $\begin{array}{c}\mathrm{Cu} \\
(\mathrm{mg} / \mathrm{l}) \\
\end{array}$ & $\begin{array}{c}\mathrm{Al} \\
(\mathrm{mg} / \mathrm{l})\end{array}$ & $\begin{array}{c}\mathrm{S} \\
(\mathrm{mg} / \mathrm{l})\end{array}$ \\
\hline $\begin{array}{l}\text { Conductivity } \\
(\mu \mathrm{S} / \mathrm{cm})\end{array}$ & 0.186 & & & & & & & & & & & \\
\hline Salinity $(\mathrm{mg} / \mathrm{l})$ & 0.175 & $0.923^{* *}$ & & & & & & & & & & \\
\hline $\begin{array}{l}\text { Phosphorus }[\mathrm{P}] \\
(\mathrm{mg} / \mathrm{l})\end{array}$ & $-0.252^{*}$ & -0.190 & -0.205 & & & & & & & & & \\
\hline $\begin{array}{l}\text { Potassium }[\mathrm{K}] \\
(\mathrm{mg} / \mathrm{l})\end{array}$ & 0.009 & -0.108 & -0.142 & $0.275^{*}$ & & & & & & & & \\
\hline $\begin{array}{l}\text { Calcium [Ca] } \\
(\mathrm{mg} / \mathrm{l})\end{array}$ & 0.188 & 0.174 & $0.222^{*}$ & $-0.251^{*}$ & $-0.466^{* *}$ & & & & & & & \\
\hline $\begin{array}{l}\text { Magnesium } \\
{[\mathrm{Mg}](\mathrm{mg} / \mathrm{l})}\end{array}$ & 0.058 & -0.022 & -0.046 & -0.091 & -0.098 & 0.126 & & & & & & \\
\hline Iron $[\mathrm{Fe}](\mathrm{mg} / \mathrm{l})$ & 0.009 & $-0.270^{*}$ & $-0.230^{*}$ & $-0.259^{*}$ & -0.178 & 0.173 & $0.261^{*}$ & & & & & \\
\hline $\begin{array}{l}\text { Manganese } \\
{[\mathrm{Mn}](\mathrm{mg} / \mathrm{l})}\end{array}$ & 0.052 & -0.109 & -0.155 & -0.203 & -0.216 & 0.177 & $0.372^{* *}$ & $0.260^{*}$ & & & & \\
\hline $\begin{array}{l}\text { Copper }[\mathrm{Cu}] \\
(\mathrm{mg} / \mathrm{l})\end{array}$ & 0.050 & -0.073 & -0.079 & -0.043 & -0.197 & 0.137 & 0.152 & 0.212 & $0.273^{*}$ & & & \\
\hline $\begin{array}{l}\text { Aluminium } \\
{[\mathrm{Al}](\mathrm{mg} / \mathrm{l})}\end{array}$ & $-0.236^{*}$ & -0.202 & -0.199 & $0.236^{*}$ & 0.153 & $-0.228^{*}$ & 0.217 & $0.288^{* *}$ & 0.033 & 0.089 & & \\
\hline $\begin{array}{l}\text { Sulphur }[\mathrm{S}] \\
(\mathrm{mg} / \mathrm{l})\end{array}$ & -0.089 & -.0153 & -0.161 & -0.057 & -0.105 & -0.039 & 0.034 & 0.004 & -0.103 & 0.112 & 0.032 & \\
\hline $\begin{array}{l}\text { Chloride }[\mathrm{Cl}] \\
(\mathrm{mg} / \mathrm{l})\end{array}$ & -0.116 & 0.167 & $0.257^{*}$ & -0.182 & -0.209 & $0.377^{* *}$ & $0.228^{*}$ & 0.189 & 0.157 & 0.124 & 0.128 & -0.005 \\
\hline
\end{tabular}

${ }^{*}$ Correlation is significant at $p<0.05 ;{ }^{* *}$ correlation is significant at $p<0.01$.

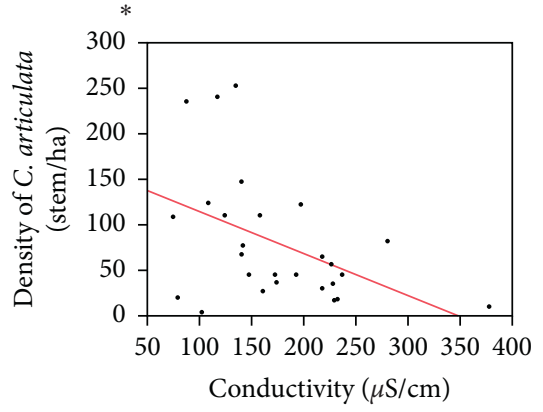

(a)

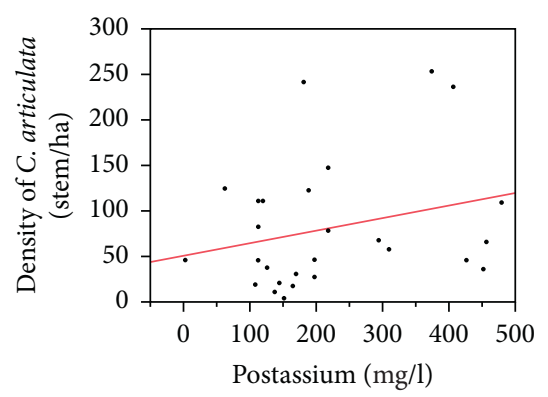

(d)

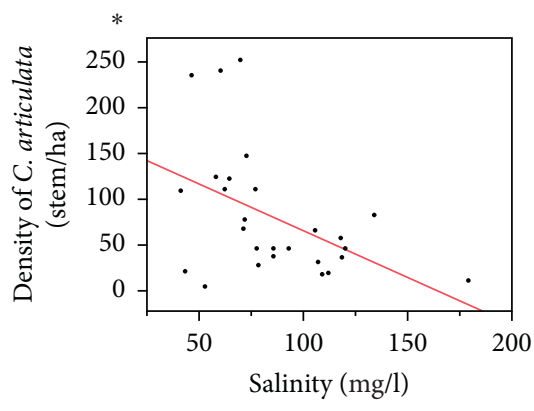

(b)

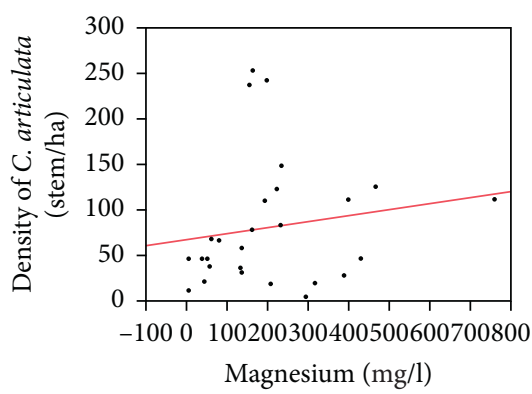

(e)

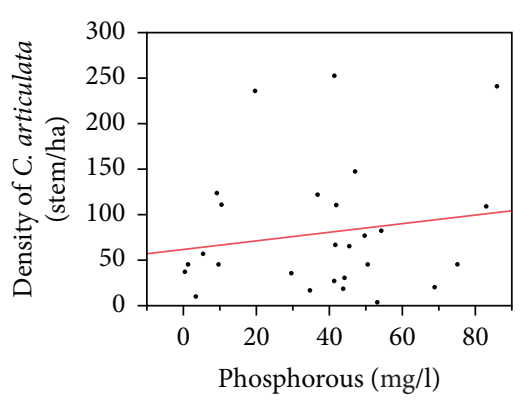

(c)

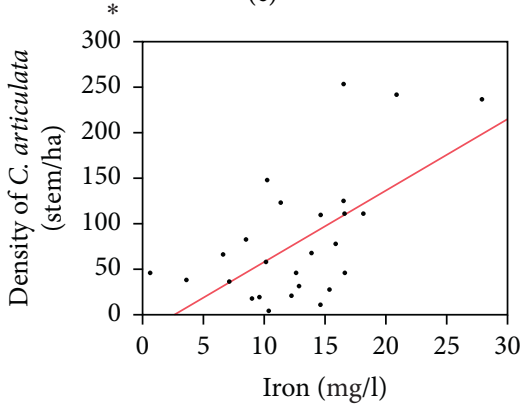

(f)

Figure 8: Continued. 


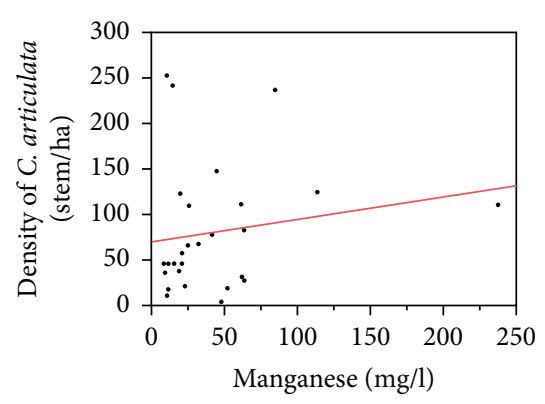

(g)

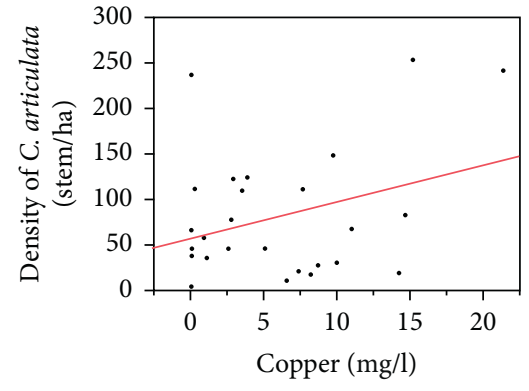

(h)

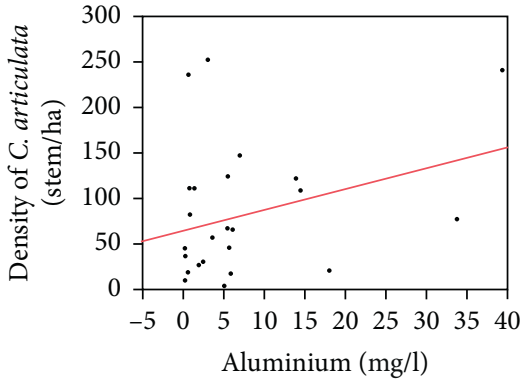

(i)

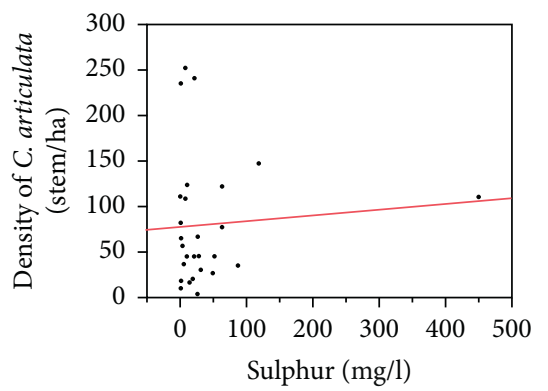

(j)

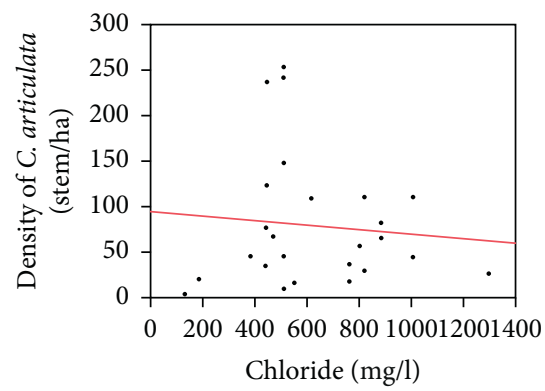

(k)

Figure 8: (a-k) Relationships between soil chemical parameters and density of $C$. articulata. Scatter plots with ${ }^{*}$ showed significant associations between density of $C$. articulata and the soil chemical parameter at $(p<0.05)$ based on the Pearson product-moment correlation coefficient.

of C. articulata (Figure 8(d)). Potassium is among the vital plant nutrients required for plant growth, reproduction, and physiology. It is not only a constituent of the plant structure but also plays a vital role in regulating several biochemical processes related to enzyme activation, carbohydrate metabolism, and protein synthesis, among others [66, 67].

Calcium plays a vital role in translocation of carbohydrates and proteins and prevents toxic accumulation of aluminium, manganese, and oxalic acid in plants [68]. Soil calcium content at the sites of occurrence of $C$. articulata varied significantly $(p<0.05)$ in the three forests with calcium levels ranging from 375.0 to $4000.0 \mathrm{mg} / \mathrm{l}$ (Figure $7(\mathrm{f})$ ). The highest calcium levels (median $=1750.0 \mathrm{mg} / \mathrm{l}$ ) were recorded in Mabira Central Forest Reserve, whereas Kibale National Park presented the lowest calcium levels (median $=1000.0 \mathrm{mg} / \mathrm{l}$ ). Soil calcium content is affected by several factors, including those related to the origin and nature of soil parent materials due to weathering and soil formation processes, topography, and water movement within the soil $[69,70]$. In any case, these may vary from one forest to another and thus lead to varying soil calcium concentrations in the three forests. Although high level of calcium is not directly harmful, it may decrease the availability of phosphorus and potassium, as evidenced in the negative relationships indicated in Table 1 .

In this study, soil magnesium $(\mathrm{Mg})$ content at sites of occurrence of $C$. articulata also varied significantly $(p<0.05)$ among the three forests (Figure $7(\mathrm{~g})$ ). Mabira forest soils presented the highest magnesium content with a median value of $291.3 \mathrm{mg} / \mathrm{l}$, while Budongo had the lowest magnesium content (median $=50.0 \mathrm{mg} / \mathrm{l}$ ). This variability may be credited to the fact that soil magnesium content is affected by several factors such as origin and nature of soil parent materials, topography, and water movement within the soil [70]. Results also indicated a positive relationship between soil magnesium content and occurrence C. articulata (Figure 8(e)). Important to note is that magnesium is the central core of the chlorophyll molecule in plant tissue and also plays a vital role in activation of specific enzyme systems [71]. Therefore, when deficient, it results in the shortage of chlorophyll leading to poor and stunted plant growth. The low magnesium concentration in soils of Budongo central forest reserve may also explain the occurrence of relatively short C. articulata stems (Figure 5(b)).

Soil iron content at sites of occurrence of $C$. articulata also varied significantly $(p<0.05)$ among the three forests (Figure 7(h)). Mabira forest soils presented the highest iron content with a median value of $18.0 \mathrm{mg} / \mathrm{l}$, while Budongo forest had the lowest soil iron content (median $=11.5 \mathrm{mg} / \mathrm{l})$. The iron content in soil is influenced by soil mineralogy, texture, and organic matter content [72]. This may account for the variability in the iron content of soils from the three forests. Results further indicated that the occurrence C. articulata generally increased with increasing levels of soil iron content (Figure 8(f)). Iron is one of the trace elements required in very small quantities for plant nutrition. It is a key element in energy transformations needed for syntheses and other biochemical processes that occur in the plant cells $[73,74]$.

Manganese $(\mathrm{Mn})$ is one of the key micronutrients in soil required in trace amounts for several plant biochemical processes. It is a constituent of some respiratory enzymes, some enzymes responsible for protein synthesis, and also plays a vital role in nitrogen metabolism $[68,75,76]$. Soil manganese content at sites of occurrence of C. articulata also 
varied significantly $(p<0.05)$ among the forests (Figure 7(i)). Mabira forest soils presented the highest manganese content with a median value of $55.3 \mathrm{mg} / \mathrm{l}$, while Budongo had the lowest manganese content (median $=12.5 \mathrm{mg} / \mathrm{l}$ ). This variability may be attributable to the fact that the behavior of $\mathrm{Mn}$ in superficial deposits is very diverse and is influenced by different environmental factors that affect its availability in the soil [74]. Although not statistically significant $(p>0.05)$, a positive relationship between soil manganese content and density of C. articulata was evident in this study (Figure $8(\mathrm{~g})$ ). Important to note is that plants need manganese in moderately variable amounts, and excessive amounts especially under low soil $\mathrm{pH}$ can be toxic when accumulated in plant tissues, thus leading to chlorosis and necrosis of the leaves [77]. On the contrary, when in low amounts, manganese deficiency which often leads to a drop in photosynthetic activity in plants [75] occurs.

Copper is another micronutrient needed by plants in very small quantities. It plays a vital role in several enzyme systems involved in the process of photosynthesis and lignin synthesis [74]. This in part is supported by the positive relationship between soil copper content and density of C. articulata shown in Figure 8(h). Results also indicated that Mabira forest soils had the highest copper content with a median value of $7.5 \mathrm{mg} / \mathrm{l}$, while Budongo had the lowest copper content with median $=1.0 \mathrm{mg} / \mathrm{l}$ (Figure $7(\mathrm{j})$ ). The results generally indicate that soils at site of occurrence of C. articulata generally had low copper content. Due to its versatility, copper has great ability to chemically interact with mineral and organic components of soil, thus rendering soluble copper concentrations extremely low [74, 78]. In any case, copper is needed in trace amounts by plants; therefore, excess amounts of copper would have detrimental effects by chiefly impacting on plant growth and morphology [75, 79].

Aluminium (Al) is among the most abundant elements in the Earth crust and a major factor that inhibits plant growth and reduces crop yield in acid soil [80]. Soil aluminium content at sites of occurrence of $C$. articulata showed minimal variation in the three forests (Figure $7(\mathrm{k})$ ). Kibale National Park soils presented the highest aluminium content with a median value of $5.6 \mathrm{mg} / \mathrm{l}$, while Budongo had the lowest aluminium content (median $=1.0 \mathrm{mg} / \mathrm{l}$ ). The results generally indicate that soils at sites of occurrence generally had low aluminium content. Some beneficial effects of aluminium on plant growth when in low concentrations have been found to induce growth stimulation by improving nutrient uptake especially in plants which have adapted to acid soils [81]. This is also evident in the positive relationship between aluminium and density of C. articulata shown in Figure 8(i). Nevertheless, aluminium when in high amounts may act as a primary factor in reducing crop yields in acid soils mostly by causing severe disruptive changes in the root system such as inhibition of root elongation [82-84].

Soils at sites of occurrence of $C$. articulata generally had low sulphur content, and this did not vary significantly $(p>0.05)$ among the forests (Figure 7(1)). Nevertheless, Kibale National Park soils presented the highest sulphur content with a median value of $15.9 \mathrm{mg} / \mathrm{l}$, while Budongo had the lowest sulphur $($ median $=10.0 \mathrm{mg} / \mathrm{l})$. The low sulphur content may be attributable to the fact that its various forms are converted to sulphates which are highly mobile and thus readily leached in soils [68]. In any case, tropical forest soils often experience intensive leaching over a long period of time, owing to a climate where precipitation always exceeds evapotranspiration [55]. Although not statistically significant $(p>0.05)$, results of this study indicated a positive relationship between soil sulphur content and density of C. articulata (Figure 8(j)). Sulphur as an essential constituent of protein is very vital in formation of chlorophyll in plants and sulphide linkages in cell walls and sulphydryl enzymes $[85,86]$, and thus, its availability in the soil impacts on productivity of the plant.

Results of the present study showed that soil chloride content at sites of occurrence of $C$. articulata ranged from $125 \mathrm{mg} / \mathrm{l}$ to $1500 \mathrm{mg} / \mathrm{l}$ (Figure $7(\mathrm{~m})$ ). Budongo Central Forest Reserve had the highest chloride content with median $=750.0 \mathrm{mg} / \mathrm{l}$, while Kibale forest had the lowest chloride content with a median $=468.3 \mathrm{mg} / \mathrm{l}$. Given the fact that chloride deposition is mainly affected by weathering process and environmental conditions, all of which may vary with location could account for variability in soil chloride content in the three forests. Nevertheless, high chloride concentrations in Budongo Central Forest Reserve may have far-reaching influence on the soil salinity. This is because increase in concentration of chloride ions in the soil solution increases soil salinity. This is shown by the positive association between chloride and salinity (Table 1). Chlorides are taken up by most plants from the soil solution primarily to balance the cations in the cell sap and regulate the osmotic pressure in the plant cells. However, high concentrations of chlorides have detrimental and toxic effects and may reduce plant yield [87-89]. This may explain the negative relationship between soil chloride content and occurrence of C. articulata evident in this study (Figure $8(\mathrm{k})$ ).

3.3. Plant Species Co-Occurring with $C$. articulata. Plant-plant species interactions play a vital role in sustaining plant communities in tropical forest ecosystems [19]. This interaction ranges from use of nutrients that are often in short supply relative to plant demand, sharing water supplies, and production of chemicals by one species that either impact directly or serve as signals to neighbors [19]. In the present study, a total of 135 plant species were sighted at the site of occurrence of C. articulata in the three selected forest areas in Uganda (Table 2). In Kibale National Park, the species majorly co-occurring with $C$. articulata were Uvariopsis congensis, Tabernaemontana holstii, Markhamia lutea, Funtumia Africana, Diospyros abyssinica, Chrysophyllum albidum, Celtis durandii, and Aphania senegalensis. In Mabira Central Forest Reserve, Acalypha neptunica, Aphania senegalensis, Blighia unijugata, Celtis spp., Funtumia elastica, and Trilepisium madagascariense were the major plant species occurring in tandem with C. articulata. In Budongo Central Forest Reserve, co-occurring species majorly included Cynometra alexandri, Celtis spp., Alchornea laxiflora, and Lasiodiscus mildbraedii. The occurrence of $C$. articulata around these 
TABLE 2: Plant species assemblages cooccurring with C. articulata.

\begin{tabular}{|c|c|c|c|c|c|}
\hline \multirow{2}{*}{ S. no. } & \multirow{2}{*}{ Species } & \multirow{2}{*}{ Family } & \multicolumn{3}{|c|}{ Occurrence (\%) } \\
\hline & & & Kibale NP & Mabira CFR & Budongo CFR \\
\hline 1 & Acalypha bipartita ${ }^{\phi}$ & Euphorbiaceae & - & 19.2 & - \\
\hline 2 & Acalypha Neptunica ${ }^{\Phi}$ & Euphorbiaceae & - & 53.9 & - \\
\hline 3 & Alangium chinense & Cornaceae & 6.5 & 3.9 & - \\
\hline 4 & Albizia coriaria $^{\Phi}$ & Leguminosae & - & 7.7 & - \\
\hline 5 & Albizia gummifera & Leguminosae & 3.2 & 11.5 & - \\
\hline 6 & Albizia grandibracteata & Leguminosae & 3.2 & 7.7 & - \\
\hline 7 & Albizia Zygia ${ }^{\Phi}$ & Leguminosae & - & 34.6 & - \\
\hline 8 & Alchornea Laxiflora ${ }^{\psi}$ & Euphorbiaceae & - & - & 57.1 \\
\hline 9 & Alstonia boonei & Apocynaceae & - & 11.5 & 7.1 \\
\hline 10 & Aningeria altissima & Sapotaceae & 9.7 & - & 7.1 \\
\hline 11 & Antiaris toxicaria & Moraceae & 6.5 & 34.6 & 3.6 \\
\hline 12 & Antidesma laciniatum ${ }^{\psi}$ & Euphorbiaceae & - & - & 10.7 \\
\hline 13 & Aphania senegalensis & Sapindaceae & 51.6 & 42.3 & - \\
\hline 14 & Balanites wilsoniana & Balanitaceae & 6.5 & - & - \\
\hline 15 & Belonophora hypoglauca ${ }^{\psi}$ & Rubiaceae & - & - & 14.3 \\
\hline 16 & Bersama abyssinica ${ }^{\neq}$ & Melianthaceae & 6.5 & - & - \\
\hline 17 & Blighia unijugata & Sapindaceae & 22.6 & 53.9 & - \\
\hline 18 & Blighia welwitschii ${ }^{\mathrm{\phi}}$ & Sapindaceae & - & 11.5 & - \\
\hline 19 & Broussonetia papyrifera $^{\phi}$ & Moraceae & - & 50.0 & - \\
\hline 20 & Caloncoba schweinfurthii ${ }^{\psi}$ & Flacourtiaceae & - & - & 10.7 \\
\hline 21 & Cassia spp. & Leguminosae & - & 3.9 & - \\
\hline 22 & Cassipourea gummifera ${ }^{\neq}$ & Rhizophoraceae & 16.1 & - & - \\
\hline 23 & Celtis africana & Ulmaceae & 19.4 & 7.7 & - \\
\hline 24 & Celtis durandii & Ulmaceae & 41.9 & 42.3 & - \\
\hline 25 & Celtis mildbraedii & Ulmaceae & - & 46.1 & 35.7 \\
\hline 26 & Celtis wightii & Ulmaceae & - & 15.4 & 35.7 \\
\hline 27 & Celtis zenkeri & Ulmaceae & - & 11.5 & 17.9 \\
\hline 28 & Chaetachme aristata & Ulmaceae & 29.0 & 19.2 & 3.6 \\
\hline 29 & Chrysophyllum albidum & Sapotaceae & 48.4 & 26.9 & 32.1 \\
\hline 30 & Chrysophyllum gorungosanum & Sapotaceae & 6.5 & 11.5 & - \\
\hline 31 & Chrysophyllum gynoecium ${ }^{\neq}$ & Sapotaceae & 6.5 & - & - \\
\hline 32 & Chrysophyllum muerense ${ }^{\psi}$ & Sapotaceae & - & - & 7.1 \\
\hline 33 & Chrysophyllum perpulchrum ${ }^{\psi}$ & Sapotaceae & - & - & 14.3 \\
\hline 34 & Cleistopholis patens ${ }^{\psi}$ & Annonaceae & - & - & 3.6 \\
\hline 35 & Coffea spp. & Rubiaceae & 16.1 & 23.1 & 10.7 \\
\hline 36 & Cola gigantea & Malvaceae & - & 23.1 & 21.4 \\
\hline 37 & Cordia africana ${ }^{\neq}$ & Boraginaceae & 6.5 & - & - \\
\hline 38 & Cordia millenii ${ }^{\psi}$ & Boraginaceae & - & - & 3.6 \\
\hline 39 & Coroton macrostachyus ${ }^{\Phi}$ & Euphorbiaceae & - & 3.9 & - \\
\hline 40 & Croton megalocarpus ${ }^{\neq}$ & Euphobiaceae & 12.9 & - & - \\
\hline 41 & Croton sylvaticus ${ }^{\psi}$ & Euphorbiaceae & - & - & 7.1 \\
\hline 42 & Cynometra alexandri & Leguminosae & 9.7 & - & 67.9 \\
\hline 43 & Desplatsia dewevrei ${ }^{\psi}$ & Malvaceae & & & 3.6 \\
\hline 44 & Diospyros abyssinica & Ebenaceae & 54.8 & 3.9 & - \\
\hline 45 & Dombeya mukole & Malvaceae & 3.2 & - & - \\
\hline 46 & Dovyalis microcalyx $x^{\neq}$ & Flacourtiaceae & 6.5 & - & - \\
\hline 47 & Drypetes ugandensis ${ }^{\psi}$ & Euphorbiaceae & - & - & 17.9 \\
\hline 48 & Ehretia cymosa ${ }^{\neq}$ & Boraginaceae & 6.5 & - & - \\
\hline 49 & Entandrophragma utile & Meliaceae & - & - & 3.6 \\
\hline 50 & Fagara angolensis ${ }^{\neq}$ & Rutaceae & 9.7 & - & - \\
\hline 51 & Fagaropsis angolensis ${ }^{\neq}$ & Rutaceae & 12.9 & - & - \\
\hline 52 & Ficus asperifolia ${ }^{\phi}$ & Moraceae & - & 11.5 & - \\
\hline 53 & Ficus brachypoda & Moraceae & 3.2 & - & - \\
\hline 54 & Ficus capensis ${ }^{\phi}$ & Moraceae & - & 3.9 & - \\
\hline 55 & Ficus dawei ${ }^{\neq}$ & Moraceae & 6.5 & - & - \\
\hline 56 & Ficus exasperata & Moraceae & 6.5 & 30.8 & 7.1 \\
\hline 57 & Ficus mucuso & Moraceae & 6.5 & 7.7 & - \\
\hline 58 & Ficus natalensis ${ }^{\phi}$ & Moraceae & - & 3.9 & - \\
\hline 59 & Ficus ovata ${ }^{\phi}$ & Moraceae & - & 3.9 & - \\
\hline
\end{tabular}


TABle 2: Continued.

\begin{tabular}{|c|c|c|c|c|c|}
\hline \multirow{2}{*}{ S. no. } & \multirow{2}{*}{ Species } & \multirow{2}{*}{ Family } & \multicolumn{3}{|c|}{ Occurrence (\%) } \\
\hline & & & Kibale NP & Mabira CFR & Budongo CFR \\
\hline 60 & Ficus saussureana ${ }^{\psi}$ & Moraceae & - & - & 3.6 \\
\hline 61 & Funtumia africana ${ }^{\neq}$ & Apocynaceae & 54.8 & - & - \\
\hline 62 & Funtumia elastica & Apocynaceae & 3.2 & 50.0 & 21.4 \\
\hline 63 & Glyphaea brevis ${ }^{\psi}$ & Malvaceae & - & - & 3.6 \\
\hline 64 & Greenwayodendron suaveolens $\psi$ & Annonaceae & - & - & 10.7 \\
\hline 65 & Guarea cedrata ${ }^{\psi}$ & Meliaceae & - & - & 7.1 \\
\hline 66 & Harungana madagascariensis & Guttiferae & 3.2 & 3.9 & 3.6 \\
\hline 67 & Holoptelea grandis & Ulmaceae & - & 7.7 & 7.1 \\
\hline 68 & Khaya anthotheca ${ }^{\psi}$ & Meliaceae & - & - & 7.1 \\
\hline 69 & Khaya senegalensis ${ }^{\phi}$ & Meliaceae & - & 7.7 & - \\
\hline 70 & Kigelia africana & Bignoniaceae & 9.7 & 7.7 & - \\
\hline 71 & Klainedoxa gabonensis ${ }^{\psi}$ & Irvingiaceae & - & - & 3.6 \\
\hline 72 & Lasiodiscus mildbraedii ${ }^{\psi}$ & Rhamnaceae & - & - & 53.6 \\
\hline 73 & Leptonychia mildbraedii ${ }^{\neq}$ & Malvaceae & 12.9 & - & - \\
\hline 74 & Linociera johnsonii & Oleaceae & 3.2 & - & - \\
\hline 75 & Lychnodiscus cerospermus ${ }^{\psi}$ & Sapindaceae & - & - & 10.7 \\
\hline 76 & Macaranga kilimandscharica & Euphorbiaceae & 3.2 & - & - \\
\hline 77 & Macaranga spinosa ${ }^{\mathrm{\phi}}$ & Euphorbiaceae & - & 15.4 & - \\
\hline 78 & Maerua duchesnei & Capparaceae & - & 3.9 & 7.1 \\
\hline 79 & Maesa lanceolata ${ }^{\neq}$ & Myrsinaceae & 3.2 & - & - \\
\hline 80 & Maesopsis eminii & Rhamnaaceae & 3.2 & - & 3.6 \\
\hline 81 & Mammea africana ${ }^{\psi}$ & Guttiferae & - & - & 7.1 \\
\hline 82 & Manilkara butugi & Sapotaceae & - & 11.5 & 3.6 \\
\hline 83 & Manilkara dawei ${ }^{\psi}$ & Sapotaceae & - & - & 3.6 \\
\hline 84 & Margaritaria discoidea & Phyllanthaceae & 3.2 & 38.5 & 7.1 \\
\hline 85 & Markhamia lutea & Sapotaceae & 41.9 & 15.4 & - \\
\hline 86 & Melanodiscus spp. ${ }^{\psi}$ & Sapindaceae & - & - & 3.6 \\
\hline 87 & Millettia dura & Leguminosae & 9.7 & - & - \\
\hline 88 & Mildbraediodendron excelsum ${ }^{\psi}$ & Leguminosae & - & - & 3.6 \\
\hline 89 & Mimusops bagshawei & Sapotaceae & 22.6 & 30.8 & - \\
\hline 90 & Monodora excelsa & Annonaceae & 16.1 & - & - \\
\hline 91 & Monodora myristica ${ }^{\phi}$ & Annonaceae & - & 3.9 & - \\
\hline 92 & Myrianthus holstii & Moraceae & 6.5 & 7.7 & 10.7 \\
\hline 93 & Neoboutonia macrocaly $x^{\neq}$ & Euphorbiaceae & 3.2 & - & - \\
\hline 94 & Newtonia buchananii & Leguminosae & 16.1 & 7.7 & - \\
\hline 95 & Pancovia turbinata ${ }^{\neq}$ & Sapindaceae & 25.8 & - & - \\
\hline 96 & Parinari excelsa ${ }^{\neq}$ & Rosaceae & 16.1 & - & - \\
\hline 97 & Phoenix spp. ${ }^{\neq}$ & Arecaceae & 6.5 & - & - \\
\hline 98 & 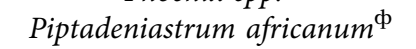 & Leguminosae & - & 11.5 & - \\
\hline 99 & Polyscias fulva & Araliaceae & 3.2 & 11.5 & - \\
\hline 100 & Premna angolensis ${ }^{\neq}$ & Verbenaceae & 9.7 & - & - \\
\hline 101 & Prunus africana & Rosaceae & 6.5 & 3.9 & - \\
\hline 102 & Pterygota mildbraedii ${ }^{\neq}$ & Malvaceae & 3.2 & - & - \\
\hline 103 & Ricinodendron heudelotii ${ }^{\psi}$ & Euphorbiaceae & - & - & 10.7 \\
\hline 104 & Rinorea ardisiaeflora ${ }^{\psi}$ & Violaceae & - & - & 21.4 \\
\hline 105 & Rinorea brachypetala ${ }^{\psi}$ & Violaceae & - & - & 17.9 \\
\hline 106 & Rinorea dentata ${ }^{\psi}$ & Violaceae & - & - & 3.6 \\
\hline 107 & Rinorea ilicifolia & Violaceae & - & 11.5 & 3.6 \\
\hline 108 & Ritchiea albersii ${ }^{\psi}$ & Capparaceae & - & - & 3.6 \\
\hline 109 & Rothmannia whitfieldii ${ }^{*}$ & Rubiaceae & 16.1 & - & - \\
\hline 110 & Sapium ellipticum ${ }^{\neq}$ & Euphorbiaceae & 9.7 & - & - \\
\hline 111 & Scolopia rhamniphylla ${ }^{\neq}$ & Flacourtiaceae & 12.9 & - & - \\
\hline 112 & Solanum mauritianum ${ }^{\neq}$ & Solanaceae & 3.2 & - & - \\
\hline 113 & Spathodea campanulata & Bignoniaceae & 3.2 & 3.9 & 14.3 \\
\hline 114 & Sterculia dawei ${ }^{\phi}$ & Malvaceae & - & 11.5 & - \\
\hline 115 & Strombosia scheffleri ${ }^{\neq}$ & Olacaceae & 12.9 & - & - \\
\hline 116 & Strombosia spp. & Olacaceae & - & 3.9 & - \\
\hline 117 & Tabernaemontana holstii & Apocynaceae & 45.2 & 50.0 & 17.9 \\
\hline 118 & Tapura fischeri ${ }^{\psi}$ & Dichapetalaceae & - & - & 3.6 \\
\hline
\end{tabular}


TABLE 2: Continued.

\begin{tabular}{|c|c|c|c|c|c|}
\hline \multirow{2}{*}{ S. no. } & \multirow{2}{*}{ Species } & \multirow{2}{*}{ Family } & \multicolumn{3}{|c|}{ Occurrence (\%) } \\
\hline & & & Kibale NP & Mabira CFR & Budongo CFR \\
\hline 119 & Teclea grandifolia ${ }^{\phi}$ & Rutaceae & - & 11.5 & - \\
\hline 120 & Teclea nobilis & Rutaceae & 71.0 & 26.9 & 3.6 \\
\hline 121 & Tetrapleura tetraptera ${ }^{\psi}$ & Leguminosae & - & - & 17.9 \\
\hline 122 & Thecocaris lucida ${ }^{\psi}$ & Euphorbiaceae & - & - & 14.3 \\
\hline 123 & Trema orientalis & Ulmaceae & - & 3.9 & 3.6 \\
\hline 124 & Trichilia dregeana & Meliaceae & 9.7 & 26.9 & - \\
\hline 125 & Trichilia mantineana ${ }^{\Phi}$ & Meliaceae & - & 11.5 & - \\
\hline 126 & Trichilia prieureana ${ }^{\psi}$ & Meliaceae & - & - & 14.3 \\
\hline 127 & Trichilia rubescens & Meliaceae & - & 42.3 & 17.9 \\
\hline 128 & Trichilia welwitschii ${ }^{\phi}$ & Meliaceae & - & 3.9 & - \\
\hline 129 & Trilepisium madagascariense & Moraceae & 19.4 & 61.5 & 7.1 \\
\hline 130 & Uvaria welwitschii ${ }^{\mp}$ & Annonaceae & 3.2 & - & - \\
\hline 131 & Uvariopsis congensis & Annonaceae & 64.5 & 3.9 & 3.6 \\
\hline 132 & Vitex amboniensis ${ }^{\psi}$ & Verbenaceae & - & - & 3.6 \\
\hline 133 & Voacanga thouarsii ${ }^{\mathrm{p}}$ & Apocynaceae & - & 19.2 & - \\
\hline 134 & Warburgia ugandensis ${ }^{\neq}$ & Canellaceae & 16.1 & - & - \\
\hline 135 & Xymalos monospora & Monimiaceae & 6.5 & - & - \\
\hline
\end{tabular}

${ }^{\Phi}$ Species was unique to sites of occurrence of C. articulata in Mabira Central Forest Reserve; ${ }^{\psi}$ species was unique to sites of occurrence of C. articulata in Budongo Central Forest Reserve; ${ }^{\neq}$species was unique to sites of occurrence of C. articulata in Kibale National Park; ${ }^{-}$species not sighted at the site of occurrence of C. articulata in that particular forest.

plant communities could be a sign that these communities provide a conducive environment for the growth and regeneration of C. articulata. Plant species of genera such as Chrysophyllum, Funtumia, Celtis, and Cynometra often form large crowns that make up the canopy layer in the forest. Studies have shown that canopy plant species often has exerting influence on microsite conditions, thus acting as a biodiversity filter upon the plants that attempt to regenerate in the understory $[90,91]$. The fact that $C$. articulata was majorly observed occurring under canopy-shaded areas is an indication that this plant species is shade tolerant. Shade-tolerant plant species are highly sensitive to the understory light heterogeneity in a tropical forest which is often influenced by the canopy cover [92]. Furthermore, plants are capable of detecting and responding to neighboring plants, thus producing consequences for plant performance and playing an important role in plant's phytochemistry [93]. This implies that neighboring plants may also have an effect on the production of secondary metabolites by $C$. articulata which consequently has an effect on the efficacy of the plant when used for medicinal purposes. Some co-occurring species such as Chryosphyllum, Cynometra, and Celtis are sought after for timber forest products (TFPs) and charcoal production. Therefore, occurrence of $C$. articulata around these plant communities increases its vulnerability to destruction or harvest. Insights into plant communities associated with C. articulata occurrence provided by this study are very important for any ex situ conservation efforts.

3.4. Implication for Ex Situ Conservation of C. articulata. Knowledge about physiographic factors governing plant growth is important for conservation and management strategies of any plant species both in situ and ex situ especially for species like C. articulata that shows restricted occurrences and is under threat from unsustainable harvesting methods, habitat degradation, and possibly climate change. In a case where forest management fails to provide the necessary protection and consequently conservation, ex situ conservation such as growing the plant outside the wild becomes a safety backup for in situ conservation and an alternative source of plant harvest and use [15]. Our findings offer insights into the soil conditions and topographical requirements of C. articulata, in addition to the associated plant species assemblages. These parameters are central to identifying suitable sites for any ex situ conservation program be it translocation, living gene banks, herbal gardens, or offsite production of $C$. articulata.

\section{Conclusion}

The current study has shown that although C. articulata is generally low occurring, it is significantly abundant in Kibale National Park, a forest currently managed by Uganda Wildlife Authority (UWA). This points to a fact that C. articulata can thrive in areas were human access, and consequently anthropogenic activities are highly restricted and therefore consequently vulnerable in Budongo and Mabira Central Forest Reserves that are not highly restricted. Therefore, this calls for continuous monitoring of species at risk such as C. articulata and enhanced and effective enforcement of existing laws governing management of Central Forest Reserves for their successful management and conservation. Findings also revealed that $C$. articulata generally occurs at moderate altitudinal landscapes with soils that are moderately acidic, low in salinity, and having considerable levels of macro- and micronutrients. C. articulata is generally associated with plant communities dominated by canopy tree species of genera such as Chryosphyllum, Celtis, Markhamia, Cynometra, Lasiodiscus, Trilepisium, Funtumia, and Diospyros, thus suggesting that 
C. articulata is a shade-tolerant species. Understanding these ecological requirements of this plant species among other things unlocks the potential for ex situ production of this plant. This will not only provide alternatives sources of plant harvest but also go a long way in relieving the current harvest pressures exerted on the wild populations of this plant species and also act as backup for in situ conservation.

\section{Data Availability}

Datasets used in this study will be made available by the corresponding author upon request.

\section{Conflicts of Interest}

The authors declare that they have no conflicts of interest.

\section{Acknowledgments}

The Pharm-Biotechnology and Traditional Medicine Centre (PHARMBIOTRAC) at Mbarara University of Science and Technology is appreciated for the technical and financial support. The authors are indebted to Uganda Wildlife Authority (UWA) and National Forestry Authority (NFA) for their support of field work. The authors highly appreciate Budongo Forest Conservation and Makerere University Biological Field stations for the field work and technical assistance rendered. The Department of Biology, Mbarara University of Science and Technology (MUST), is highly valued for the technical support. This research was supported by The Pharm-Biotechnology and Traditional Medicine Centre (PHARMBIOTRAC) program with financial support from the World Bank to Eastern and Southern Africa Higher Education Centers of Excellence (ACE II) Program at Mbarara University of Science and Technology.

\section{References}

[1] J. O. Kokwaro, Flora of Tropical East Africa, Rutaceae. Royal Botanic Gardens, London, UK, 1982.

[2] J. Hutchinson and J. M. Dalziel, "Flora of west tropical Africa," Nature, vol. 139, 1958.

[3] P. C. Swingle and W. T. Reece, "The botany of Citrus and its wild relatives," in The Citrus Industry, W. Reuther, H. Webber, and L. D. Batchelor, Eds., pp. 190-430, University of California, Riverside, CA, USA, 1967.

[4] P. Vudriko, M. Baru, J. Kateregga, and J. Ndukui, "Crude ethanolic leaf extracts of Citropsis articulata: a potential phytomedicine for treatment of male erectile dysfunction associated with testosterone deficiency," International Journal of Basic \& Clinical Pharmacology, vol. 3, no. 1, pp. 120-123, 2014.

[5] D. Lacroix, S. Prado, D. Kamoga, J. Kasenene, and B. Bodo, "Structure and in vitro antiparasitic activity of constituents of Citropsis articulata root bark," Journal of Natural Products, vol. 74, no. 10, pp. 2286-2289, 2011.

[6] J. Obua, J. G. Agea, and J. J. Ogwal, "Status of forests in Uganda," African Journal of Ecology, vol. 48, no. 4, pp. 853-859, 2010.
[7] National Forestry Authority, Strategic Action Plan for the Period 2008/9 to 2012/13 with Priorities for the First Five Years, National Forestry Authority, Kampala, Uganda, 2008.

[8] W. Olupot and E. Sande, "Evaluating the status of forest understory plants on high demand in an "open access" setting for restoration and community engagement," Heliyon, vol. 5, no. 4, Article ID e01468, 2019.

[9] UWA: Kibale National Park, Management Plan 2015-2024, UWA: Kibale National Park, Kampala, Uganda, 2015.

[10] MTWA, Red List of Treatened Species of Uganda 2018, MTWA, Kampala, Uganda, 2018.

[11] A. Okeowo, "“Sex tree," other medicinal plants near extinction in Uganda," 2007, http://news.nationalgeographic.com/ news/2007/08/070803-sex-tree.html.

[12] J. Passioura, "Soil structure and plant growth," Soil Research, vol. 29, no. 6, pp. 717-728, 1991.

[13] J. B. Passioura, "Soil conditions and plant growth," Plant, Cell \& Environment, vol. 25, no. 2, pp. 311-318, 2002.

[14] E. J. Russell, Soil Conditions and Plant Growth, Wiley, Hoboken, NJ, USA, 1951.

[15] C. A. Offord, P. F. Meagher, and H. C. Zimmer, "Growing up or growing out? How soil $\mathrm{pH}$ and light affect seedling growth of a relictual rainforest tree," AoB Plants, vol. 6, 2014.

[16] L. Bernstein, "Effects of salinity and sodicity on plant growth," Annual Review of Phytopathology, vol. 13, no. 1, pp. 295-312, 1975.

[17] M. A. Leibold, M. Holyoak, N. Mouquet et al., "The metacommunity concept: a framework for multi-scale community ecology," Ecology Letters, vol. 7, no. 7, pp. 601-613, 2004.

[18] R. F. Silva, G. B. P. Rabeschini, G. L. R. Peinado et al., "The ecology of plant chemistry and multi-species interactions in diversified agroecosystems," Frontiers in Plant Science, vol. 9, p. 1713, 2018.

[19] J. J. Ewel and A. J. Hiremath, "Plant-plant interactions in tropical forests," Biotic Interactions in the Tropics, Cambridge University Press, Cambridge, UK, pp. 3-34, 2005.

[20] F. Kabi, C. Masembe, V. Muwanika, H. Kirunda, and R. Negrini, "Geographic distribution of non-clinical Theileria parva infection among indigenous cattle populations in contrasting agro-ecological zones of Uganda: implications for control strategies," Parasites \& Vectors, vol. 7, no. 1, p. 414, 2014.

[21] Ministry of Water and Environment, Revised Forest Management Plan for Mabira Central Forest Reserves for the Period July 2010-June 2020, Ministry of Water and Environment, Kampala, Uganda, 2017.

[22] P. C. Howard, J. Butler, and P. Howard, Nature Conservation in Uganda's Tropical Forest Reserves, IUCN, Cambridge, UK, 1991.

[23] J. W. Pallister, The Geology of Southern Mengo, Geological Survey of Uganda, Kampala, Uganda, 1959.

[24] P. Tugume, E. K. Kakudidi, M. Buyinza et al., "Ethnobotanical survey of medicinal plant species used by communities around Mabira central forest reserve, Uganda," Journal of Ethnobiology and Ethnomedicine, vol. 12, no. 1, pp. 1-28, 2016.

[25] I. Langdale-Brown, H. A. Osmaston, and J. G. Wilson, The Vegetation of Uganda and Its Bearing on Land-Use, Government of Uganda, Kampala, Uganda, 1964.

[26] D. Baranga, "Observations on resource use in Mabira forest reserve, Uganda," African Journal of Ecology, vol. 45, no. s1, pp. 2-6, 2007.

[27] J.-M. Boffa, R. Kindt, B. Katumba, J.-G. Jourget, and L. Turyomurugyendo, "Management of tree diversity in 
agricultural landscapes around Mabira forest reserve, Uganda," African Journal of Ecology, vol. 46, no. s1, pp. 24-32, 2008.

[28] G. Bush, S. Nampindo, C. Aguti, and A. Plumptre, The Value of Uganda's Forests: A Livelihoods and Ecosystems Approach, Wildlife Conservative Society, Kampala, Uganda, 2004.

[29] W. J. Eggeling, "Observations on the ecology of the Budongo rain forest, Uganda," The Journal of Ecology, vol. 34, no. 1, pp. 20-87, 1947.

[30] J. B. Bahati, "Effects of logging on environmental factors, natural regeneration, and distribution of selected mahogany species in Budongo forest reserve, Uganda," 2005, http://dlc. dlib.indiana.edu/dlc/bitstream/handle/10535/3554/ BahatiDissertation.pdf.

[31] M. Tweheyo, K. A. Lye, and R. B. Weladji, "Chimpanzee diet and habitat selection in the Budongo forest reserve, Uganda," Forest Ecology and Management, vol. 188, no. 1-3, pp. 267278, 2004.

[32] A. J. Plumptre and V. Reynolds, "Censusing chimpanzees in the Budongo forest, Uganda," International Journal of Primatology, vol. 17, no. 1, pp. 85-99, 1996.

[33] P. Howard, T. Davenport, and F. Kigenyi, "Planning conservation areas in Uganda's natural forests," Oryx, vol. 31, no. 4, pp. 253-264, 1997.

[34] T. Wagner, "Seasonal changes in the canopy arthropod fauna in Rinorea beniensis in Budongo forest, Uganda," Tropical Forest Canopies: Ecology and Management, vol. 153, no. 1-2, pp. 169-178, 2001.

[35] A. J. Plumptre, "Changes following 60 years of selective timber harvesting in the Budongo forest reserve, Uganda," Forest Ecology and Management, vol. 89, no. 1-3, pp. 101-113, 1996.

[36] M. Tweheyo and J. Obua, "Feeding habits of chimpanzees (Pan troglodytes), red-tail monkeys (Cercopithecus ascanius schmidti) and blue monkeys (Cercopithecus mitis stuhlmanii) on figs in Budongo forest reserve, Uganda," African Journal of Ecology, vol. 39, no. 2, pp. 133-139, 2001.

[37] M. Tweheyo, D. M. Tumusiime, T. Muhairwe, and R. Twinomuhangi, "Elephant damage and tree response in restored parts of Kibale national park, Uganda," International Journal of Biodiversity and Conservation, vol. 5, no. 6, pp. 371-377, 2013.

[38] R. J. Lilieholm, J. M. Kasenene, G. Isabirye-Basuta, T. L. Sharik, and K. B. Paul, "Research opportunites at the Makerere University biological field station, Uganda," Bulletin of the Ecological Society of America, vol. 78, no. 1, pp. 80-84, 1997.

[39] J. N. Hartter, Landscape Change around Kibale National Park, Uganda: Impacts on Land Cover, Land Use, and Livelihoods, University of Florida, Gainesville, FL, USA, 2007.

[40] A. Byaruhanga, P. Kasoma, and D. Pomeroy, "Important bird areas in Africa and associated islands-Uganda," 2011, http:// www.natureuganda.org/downloads/IBA.pdf.

[41] R. Scoon, Geology of National Parks of South-Western Uganda: Basement Terranes and Volcanism in the Albertine Rift, Kibale National Park, Kampala, Uganda, 2018.

[42] C. A. Chapman and J. E. Lambert, "Habitat alteration and the conservation of African primates: case study of Kibale national park, Uganda," American Journal of Primatology, vol. 50, no. 3, pp. 169-185, 2000.

[43] C. A. MacKenzie, J. Salerno, J. Hartter et al., "Changing perceptions of protected area benefits and problems around Kibale national park, Uganda," Journal of Environmental Management, vol. 200, pp. 217-228, 2017.
[44] R. E. McRoberts, E. O. Tomppo, and R. L. Czaplewski, "Sampling designs for national forest assessments," Knowledge Reference for National Forest Assessments, pp. 23-40, FAO, Rome, Italy, 2015.

[45] A. C. Hamilton, A Field Guide to Uganda Forest Trees, Makerere University, Kampala, Uganda, 1981.

[46] J. Kalema and H. Beentje, Conservation Checklist of the Trees of Uganda, Royal Botanic Gardens Kew, London, UK, 2012.

[47] A. B. Katende, A. Birnie, and B. O. Tengnäs, Useful Trees and Shrubs for Uganda: Identification, Propagation, and Management for Agricultural and Pastoral Communities, Regional Soil Conservation Unit, Nairobi, Kenya, 1995.

[48] R. Burt, Soil Survey Field and Laboratory Methods Manual, USDA, Washington, DC, USA, 2014.

[49] L. Walthert and E. S. Meier, "Tree species distribution in temperate forests is more influenced by soil than by climate," Ecology and Evolution, vol. 7, no. 22, pp. 9473-9484, 2017.

[50] P. Shrivastava and R. Kumar, "Soil salinity: a serious environmental issue and plant growth promoting bacteria as one of the tools for its alleviation," Saudi Journal of Biological Sciences, vol. 22, no. 2, pp. 123-131, 2015.

[51] Z. Ou, S. Pang, Q. He, Y. Peng, X. Huang, and W. Shen, "Effects of vegetation restoration and environmental factors on understory vascular plants in a typical karst ecosystem in southern China," Scientific Reports, vol. 10, no. 1, pp. 1-10, 2020.

[52] T. Ohdo and K. Takahashi, "Plant species richness and community assembly along gradients of elevation and soil nitrogen availability," AoB Plants, vol. 12, no. 3, Article ID plaa014, 2020.

[53] G. W. Thomas, "Soil pH and soil acidity," Methods of Soil Analysis, Part 3: Chemical Methods, vol. 5, pp. 475-490, 1996.

[54] K. Fujii, A. Hartono, S. Funakawa, M. Uemura, T. Sukartiningsih, and T. Kosaki, "Acidification of tropical forest soils derived from serpentine and sedimentary rocks in east Kalimantan, Indonesia," Geoderma, vol. 160, no. 3-4, pp. 311-323, 2011.

[55] K. Fujii, M. Shibata, K. Kitajima, T. Ichie, K. Kitayama, and B. L. Turner, "Plant-soil interactions maintain biodiversity and functions of tropical forest ecosystems," Ecological Research, vol. 33, no. 1, pp. 149-160, 2018.

[56] W. H. McDowell, "Internal nutrient fluxes in a Puerto Rican rain forest," Journal of Tropical Ecology, vol. 14, no. 4, pp. 521-536, 1998.

[57] Z. Lončarić, K. Karalić, B. Popović, D. Rastija, and M. Vukobratović, "Total and plant available micronutrients in acidic and calcareous soils in Croatia," Cereal Research Communications, vol. 36, pp. 331-334, 2008.

[58] U.S. Department of Agriculture-Natural Resources Conservation Service, National Soil Survey Handbook, USDA, Washington, DC, USA, 2017.

[59] J. Le Bot, S. Adamowicz, and P. Robin, "Modelling plant nutrition of horticultural crops: a review," Scientia Horticulturae, vol. 74, no. 1-2, pp. 47-82, 1998.

[60] X. Ding, Y. Jiang, H. Zhao et al., "Electrical conductivity of nutrient solution influenced photosynthesis, quality, and antioxidant enzyme activity of pakchoi (Brassica campestris L. ssp. Chinensis) in a hydroponic system," PLoS One, vol. 13, no. 8, Article ID e0202090, 2018.

[61] I. C. R. Holford, "Soil phosphorus: its measurement, and its uptake by plants," Soil Research, vol. 35, no. 2, pp. 227-240, 1997. 
[62] M. Razaq, P. Zhang, and H. Shen, "Influence of nitrogen and phosphorus on the growth and root morphology of Acer mono," PLoS One, vol. 12, no. 2, Article ID e0171321, 2017.

[63] M. S. Guignard, A. R. Leitch, C. Acquisti et al., "Impacts of nitrogen and phosphorus: from genomes to natural ecosystems and agriculture," Frontiers in Ecology and Evolution, vol. 5, p. 70, 2017.

[64] A. F. Cross and W. H. Schlesinger, "A literature review and evaluation of the Hedley fractionation: applications to the biogeochemical cycle of soil phosphorus in natural ecosystems," Geoderma, vol. 64, no. 3-4, pp. 197-214, 1995.

[65] E. D. Kaiser and J. C. Rosen, Potassium for Crop Production, University of Minnesota, Minneapolis, MN, USA, 2018.

[66] M. Hasanuzzaman, M. Bhuyan, K. Nahar et al., "Potassium: a vital regulator of plant responses and tolerance to abiotic stresses," Agronomy, vol. 8, no. 3, p. 31, 2018.

[67] X. Xu, X. Du, F. Wang et al., "Effects of potassium levels on plant growth, accumulation and distribution of carbon, and nitrate metabolism in apple dwarf rootstock seedlings," Frontiers in Plant Sciences, vol. 11, 2020.

[68] U.S. Department of Agriculture, Agronomy Technical Note No. 54: Soil Fertility Soil, USDA, Poetland, OR, USA, 1985.

[69] T. G. Huntington, R. P. Hooper, C. E. Johnson, B. T. Aulenbach, R. Cappellato, and A. E. Blum, "Calcium depletion in a southeastern United States forest ecosystem," Soil Science Society of America Journal, vol. 64, no. 5, pp. 1845-1858, 2000.

[70] J. M. Kabrick, K. W. Goyne, Z. Fan, and D. Meinert, "Landscape determinants of exchangeable calcium and magnesium in Ozark highland forest soils," Soil Science Society of America Journal, vol. 75, no. 1, pp. 164-180, 2011.

[71] E. D. Kaiser and J. C. Rosen, "Magnesium for crop production," 2016, https://extension.umn.edu/micro-andsecondary-macronutrients/magnesium-crop-production.

[72] G. F. Mielki, R. F. Novais, J. C. Ker, L. Vergütz, and G. F. de Castro, "Iron availability in tropical soils and iron uptake by plants," Revista Brasileira de Ciência do Solo, vol. 40, 2016.

[73] N. K. Boardman, “Trace elements in photosynthesis," in Trace Elements in Soil-Plant-Animal SystemsElsevier, Amsterdam, Netherlands, 1975.

[74] A. Kabata-Pendias, Trace Elements in Soils and Plants, CRC Press, Boca Raton, FL, USA, 2010.

[75] H. Marschner, Mineral Nutrition of Higher Plants, Academic Press, Cambridge, MA, USA, 1995.

[76] V. Lanquar, M. S. Ramos, F. Lelièvre et al., "Export of vacuolar manganese by AtNRAMP3 and AtNRAMP4 is required for optimal photosynthesis and growth under manganese deficiency," Plant Physiology, vol. 152, no. 4, pp. 1986-1999, 2010.

[77] E. G. Mulder and F. C. Gerretsen, "Soil manganese in relation to plant growth," Advances in Agronomy, Elsevier, Amsterdam, Netherlands, pp. 221-277, 1952.

[78] S. Sauvé, M. B. McBride, W. A. Norvell, and W. H. Hendershot, "Copper solubility and speciation of in situ contaminated soils: effects of copper level, $\mathrm{pH}$ and organic matter," Water, Air, and Soil Pollution, vol. 100, no. 1-2, pp. 133-149, 1997.

[79] A. R. Sheldon and N. W. Menzies, "The effect of copper toxicity on the growth and root morphology of Rhodes grass (Chloris gayana Knuth.) in resin buffered solution culture," Plant and Soil, vol. 278, no. 1-2, pp. 341-349, 2005.

[80] N. Muhammad, G. Zvobgo, and Z. Guo-ping, "A review: the beneficial effect of aluminum on plant growth in acid soil and the possible mechanisms," Journal of Integrative Agriculture, vol. 17, pp. 60345-60347, 2018.

[81] M. Osaki, T. Watanabe, T. Ishizawa et al., "Nutritional characteristics in leaves of native plants grown in acid sulfate, peat, sandy podzolic, and saline soils distributed in peninsular Thailand," Plant and Soil, vol. 201, no. 2, pp. 175-182, 1998.

[82] Q. Ma, Z. Rengel, and J. Kuo, "Aluminium toxicity in rye (Secale cereale): root growth and dynamics of cytoplasmic $\mathrm{Ca}^{2+}$ in intact root tips," Annals of Botany, vol. 89, no. 2, pp. 241-244, 2002.

[83] E. Bojórquez-Quintal, C. Escalante-Magaña, I. EchevarríaMachado, and M. Martínez-Estévez, "Aluminum, a friend or foe of higher plants in acid soils," Frontiers in Plant Science, vol. 8, p. 1767, 2017.

[84] P. M. Kopittke and F. P. C. Blamey, "Theoretical and experimental assessment of nutrient solution composition in short-term studies of aluminium rhizotoxicity," Plant and Soil, vol. 406, no. 1-2, pp. 311-326, 2016.

[85] C. Williams and A. Steinbergs, "Soil sulphur fractions as chemical indices of available sulphur in some Australian soils," Australian Journal of Agricultural Research, vol. 10, no. 3, pp. 340-352, 1959.

[86] D. Vaughan and R. E. Malcolm, Soil Organic Matter and Biological Activity, Springer Science \& Business Media, Berlin, Germany, 2012.

[87] G. Xu, H. Magen, J. Tarchitzky, and U. Kafkafi, "Advances in chloride nutrition of plants," Advances in Agronomy, Elsevier, Amsterdam, Netherlands, pp. 97-150, 1999.

[88] P. White and M. R. Broadley, "Chloride in soils and its uptake and movement within the plant: a review," Annals of Botany, vol. 88, no. 6, pp. 967-988, 2001.

[89] J. M. Colmenero-Flores, J. D. Franco-Navarro, P. CuberoFont, P. Peinado-Torrubia, and M. A. Rosales, "Chloride as a beneficial macronutrient in higher plants: new roles and regulation," International Journal of Molecular Sciences, vol. 20, no. 19, p. 4686, 2019.

[90] S. W. Beatty, "Influence of microtopography and canopy species on spatial patterns of forest understory plants," Ecology, vol. 65, no. 5, pp. 1406-1419, 1984.

[91] S. Gandolfi, C. A. Joly, and R. R. Rodrigues, "Permeability-impermeability: canopy trees as biodiversity filters," Scientia Agricola, vol. 64, no. 4, pp. 433-438, 2007.

[92] R. Montgomery and R. Chazdon, "Light gradient partitioning by tropical tree seedlings in the absence of canopy gaps," Oecologia, vol. 131, no. 2, pp. 165-174, 2002.

[93] C.-H. Kong, S.-Z. Zhang, Y.-H. Li et al., "Plant neighbor detection and allelochemical response are driven by rootsecreted signaling chemicals," Nature Communications, vol. 9, no. 1, pp. 1-9, 2018. 